\title{
The presentation of Jesus in the missionary speeches of Acts and the mission of the church
}

\begin{abstract}
Author:
Christoph W. Stenschke ${ }^{1,2}$

Affiliations:

${ }^{1}$ Biblisch-Theologische

Akademie, Forum Wiedenest,

Germany

${ }^{2}$ Department of Biblical and Ancient Studies, University of South Africa, South Africa

Correspondence to:

Christoph Stenschke

Email:

stenschke@wiedenest.de

Postal address:

PO Box 392, Pretoria 0003

South Africa

Dates:

Received: 12 Oct. 2012

Accepted: 03 Mar. 2014

Published: 30 June 2014

How to cite this article: Stenschke, C.W., 2014, 'The presentation of Jesus in the missionary speeches of Acts and the mission of the church', Verbum et Ecclesia 35(1), Art. \#803, 18 pages. http://dx.doi.org/10.4102/ ve.v35i1.803
\end{abstract}

\section{Copyright:}

(C) 2014. The Authors. Licensee: AOSIS OpenJournals. This work is licensed under the Creative Commons Attribution License.

\section{Read online:}

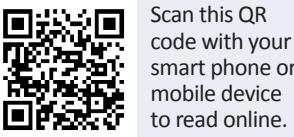

This article first discusses the methodological issues involved in examining the portrayal of Jesus in the missionary speeches of the book of Acts and the nature of these speeches. This is followed by a detailed analysis of the presentation of Jesus, following a chronological line: Jesus' origin, his ministry, suffering, death and burial, his resurrection, exaltation, present ministry and parousia. The analysis is supplemented by the various portrayals of Jesus in the narrative of Acts. Afterwards, a detailed interpretation of this portrayal is offered, that is, its emphases (namely the saving significance of all of Jesus' life, the pervasive motif of the fulfilment of Scripture, Jesus as the agent of God, and the Jewishness of his life and ministry, focussing on Israel), the consequences that are drawn from this portrayal, the impact of the audiences on the presentation of Jesus, and the use of Christological titles. A final section reflects on the implications of the portrayal of Jesus in the missionary speeches of Acts for the witness and proclamation of the church. This comprehensive approach accounts for the length of the article.

Intradisciplinary and/or interdisciplinary implications: Some research has criticised LukeActs for its alleged lack of Pauline theology and the 'depth' of Paul's interpretation of the life, death and resurrection of Jesus. This article shows that Acts in its own way offers a significant summary and Christological and soteriological interpretation of the life of Jesus and its enduring significance. The article also reflects on the significance of this interpretation for the present day presentation of Jesus and provides some necessary corrections.

\section{Introduction}

For a number of reasons, searching for Jesus in the missionary speeches of Acts is a challenging task: ${ }^{1}$ Firstly, the speeches in Acts are summaries of what was supposed to have been said on a particular occasion. For example, Acts 2:40 indicates that 'with many other words Peter bore witness and continued to exhort them, saying ...' It is also historically plausible that Peter's sermon on the Jewish feast of weeks lasted for more than $80 \mathrm{~s}-90 \mathrm{~s}^{2}$ To reiterate: we are not dealing with complete speeches, but with summaries. ${ }^{3}$

Secondly, although delivered before various audiences, the missionary speeches in Acts are primarily formulated with the readers of all of Luke-Acts in mind. After having read the gospel, these readers are familiar with the aspects of the life of Jesus that Luke chose to emphasise (Lk 1:1-4). ${ }^{4}$ There was therefore no need to repeat, in the second volume, much of the biography of Jesus, which the readers of the gospel knew already. ${ }^{5}$ Some content, perhaps much of what might actually have been said on the occasion of a particular speech about the biography of Jesus, will have been omitted.

\section{As M. Korn (1993) observes:}

The proclamation of Jesus in the missionary speeches presents only a skeleton in order to show their dependence on the past history of Jesus. For the readers of Acts the flesh for this skeleton comes from the

1.On the missionary speeches, see Gempf (1988) and Stenschke (1999). The strong emphasis on the speeches of Acts in the 1970 s and 1980s (this is where Luke's theology was - almost exclusively - to be found!) has given way to neglect of the speeches in more recent research. For example, the volume of Frey, Rothschild and Schröter (2009) of 625 pages does not contain a single essay on the speeches. Obviously, the speeches need to be seen in their narrative contexts.

2.Acts 20:9, 11 suggest that Paul could speak for a long time. Even if one allows for generous literary revision, the speeches of contemporary orators such as Cicero give an indication as to the actual length of ancient speeches. The speeches that appear in the works of ancient historians differ in length.

3.See Bauckham (1996:185-217). On the significance and function of public speeches in the writings of ancient historians, see Gempf (1993:259-303).

4.For detailed discussion, see Marshall (1993:163-182) and the discussion in Marshall (1992:43-46).

5.It would be interesting to trace all the allusions and echoes to passages in Luke's Gospel in the speeches of Acts and to examine how they function in recalling the story of Jesus in greater detail than the summaries in the speeches can provide. For the sake of length, this cannot be achieved in this article as it would require a study of its own. In some cases, the portrayal of Jesus in the speeches may diverge from the presentation in Luke's Gospel. In the speeches of Acts themselves, there are some differences. Some of the methodology developed to discern and interpret allusions and echoes to the Old Testament in Luke-Acts and other New Testament writings would be helpful in this quest. As a continuous reminder of the close relationship with the presentation of Jesus in Luke's Gospel, I note the relevant passages when examining the portrayal of him in Acts. An interesting parallel is the relationship of various kinds of references in the speeches in the writings of Flavius Josephus to events narrated earlier on in the account or the same phenomenon in other ancient historians. 
Gospel of Luke. For good reasons the beginning of Acts refers to the gospel (Acts 1.1f) as the presupposition for the following second volume. (p. 216) ${ }^{6}$

In addition, representative speeches by a person (either Peter or Paul) before representative audiences (Jews in Jerusalem, Gentiles in Caesarea, and Jews in the diaspora) are reported in some detail. ${ }^{7}$ In the case of speeches delivered on later occasions, short summaries are deemed to suffice, given that readers are familiar with the content and argument of the earlier speeches.

In past research some scholars have drawn far-reaching conclusions about Lukan theology from the alleged 'omissions' in the speeches of Acts. For example, the fact that the biography of Jesus does not appear in the speeches in Lystra and Athens caused U. Wilckens to conclude that this biography was no longer relevant. In the words of Korn (1993):

Do these two sermons represent a new phase in the history of the church, i.e. the Gentile Christian mission, in which the past history of Jesus does not play a role any longer? Wilckens assumed this and concluded that, in Luke's own time, the Jesus-material was no longer relevant for the purposes of the missionary proclamation and that is was only in catechesis that this material still played a role. (p. 216)

Given the nature of the missionary speeches in Acts (i.e. as summaries), and given that Acts is Luke's second volume and that Luke avoids repetition, such conclusions are highly questionable.

Thirdly, the narrative setting of the different missionary speeches needs to be considered carefully. ${ }^{9}$ In Luke's portrayal, some of the speeches in Acts were delivered before audiences of people who were roughly or thoroughly familiar with the biography of Jesus. This applies to the missionary speeches in Jerusalem in Acts 2 and 3 and to the defence speeches of the apostles before the religious leaders of Jerusalem. After all, the religious establishment kept a close eye on John the Baptist and Jesus from an early stage: 'Pharisees and teachers of the Law were sitting there, who had come from every village in Galilee and Judaea and from Jerusalem' (Lk 5:17). When Jesus entered Jerusalem, he was no stranger. In addition, he spent several days in the city before his death. The disciples on the road to Emmaus

6.Earlier studies are Gewieß (1939), Delling (1972/1973:373-389) and Glöckner (1976)

7.Luke reports in some detail Paul's first missionary speech in Acts 13:16-41; see Bayer (1998:257-274) and Hansen (1998:295-324).

8.With reference to Wilckens (1974), Schweizer (1957:1-11) argued that 'over agains Gentiles and Jews concerning whom nothing negative is known, as, for example, the Gentiles in the house of Cornelius and the Jews in Pisidian Antioch, the call to repentance, combined with the identification and correction of a misunderstanding, is missing. In a strict sense, these people do not even need the salvation offered to them in the name of Jesus that consists of the offer of repentance and forgivenes of sins (see among others Luke 24:17)' summary according to Korn (1993.220). Schweizer's case has later been argued in detail by Taeger (1980:96-108, 1982). Schweizer's case has later been argued in detail by Taeger (1980:96-108, 1982). have argued against this case in Stenschke (1999). Pichler (1997:63) merely notes: 'The audience of Acts 13:16-41 is not charged with an explicit call to repentance. They are neither guilty of polytheism nor, up to this moment, of the rejection of
Jesus.'

9.See the section 'Identifying the Speeches' in Soards (1994:18-21). For a recent discussion of the sources of Acts, see Pervo (2009:12-14). rightly assumed that everybody in the city would be familiar with the recent events concerning Jesus (Lk 24:18: 'Are you the only visitor to Jerusalem who does not know the things that have happened there in these days?'). If, as C. Gempf (1988) persuasively argues, there is historical and literary appropriateness, it is not to be expected that the speeches of the early chapters of Acts present the biography of Jesus in much detail. Instead, they focus on his identity and significance and, in particular, on the resurrection, which proved Jesus to be the Messiah and which was inevitably a contentious matter (cf. Mt 27:62-28:15; Ac 4:2).

Fourthly, the speeches should not be studied apart from their wider narrative contexts. ${ }^{10}$ The speeches in Acts have often been studied as particularly important sources for Lukan theology, and there is a case to be made for this approach. Luke chose not to publish a collection of speeches, however, but a narrative in which the speeches are carefully embedded. ${ }^{11}$ Speeches and narrative must not be separated from each other. The portrait of Jesus in the speeches therefore needs to be seen against the wider narrative characterisation of Jesus in all of Acts.

Does this influence our understanding of the biography of Jesus in the missionary speeches? The answer to this question is both 'yes' and 'no'. No, because the references to the biography of Jesus occur (with the exception of Acts 1:1-9 and few other occurrences) in speeches, be they missionary speeches or other speeches in Acts (see below).

Acts 1:1-9 describes the last earthly phase of the biography of Jesus:

Jesus gave commands through the Holy Spirit to the apostles whom he had chosen. He presented himself alive to them after his sufferings by many proofs, appearing to them during forty days and speaking about the kingdom of God. (vv. 2-4)

He announces the coming of the Spirit whom they are to await in Jerusalem. He tells them to wait for the times and seasons fixed by the Father for the restoration of Israel and he commissions them to be his witnesses in Jerusalem, Judaea, Samaria and to the end of the earth (v. 8). In the speeches in Acts, the disciples are portrayed as witnessing to Jesus. The ascension of Jesus brings the resurrection appearances of forty days to an end. The book of Acts starts with the events (resurrection appearances and ascension) of which the disciples become witnesses and to which they witness in their missionary speeches.

Yet we can also answer 'yes', because the biography of Jesus is presupposed and present also in the narrative sections of Acts. It has often been observed that part of Luke's purpose in his presentation is to emphasise the parallels between Paul and Peter in order to show that Paul was no lesser an apostle than Peter. Luke, however, also portrays Peter's and Paul's

10.I have previously argued this case in Stenschke (1999). The classic study on the missionary speeches of Acts, Wilckens (1974:56-71), also analyses the settings of these speeches.

11.For a discussion of the genre of Acts, see Palmer (1993:1-29). 
experiences as being parallel to the experiences of Jesus. ${ }^{12}$ The biography of Jesus is behind Luke's portrayal of Peter and of Paul. Also, some narrative sections of Acts contain references to Jesus, mainly in their reports of the contents of the Christian proclamation. There the biography of Jesus usually appears condensed in Christological titles, which express the significance of Jesus' biography.

In this context two cases merit special attention. The speeches in Lystra and in Athens (14:15-27; 17:22-31) delivered before Gentile audiences ${ }^{13}$ do not mention Jesus. Jesus only appears anonymously in Acts 17:31: 'by a man whom he has appointed ... by raising him from the dead'. On both occasions, however, some aspects of the biography of Jesus appear indirectly or directly in the narrative context prior to the speeches: upon listening to Paul's proclamation, a lame man in Lystra 'had faith to be made well' (14:9). This response in faith suggests that Paul must have spoken about Jesus, his ministry of healing and its significance (cf. Ac 2:22). The lame man somehow also knew that the possibility of healing did not apply to a distant past, but also to the present. Paul's proclamation before this Gentile audience apparently included the ministry, death, resurrection and exaltation of Jesus, including the notion that such miracles are still possible where and when people in need respond in faith. ${ }^{14}$

Paul's initial proclamation on the Athenian agora concerned Jesus and the resurrection (17:18). The reference to 'the resurrection' probably does not refer to the general resurrection of the dead, but to the resurrection of Jesus: 'Jesus and his resurrection'. ${ }^{15}$ If Paul spoke about Jesus and his resurrection, he must also have mentioned the death of Jesus and must have somehow explained the circumstances that led to this death; Paul must also have referred to the exceptional nature of Jesus. In addition, it would only be natural if his proclamation also included some information on what happened to this Jesus after the resurrection. Did Paul use some titular designation for Jesus? ${ }^{16}$

Because of the proclamation of 'Jesus and the resurrection', some Athenians thought that Paul was proclaiming two foreign deities, one male god named Jesus and his female companion Anastasis. What in Paul's presentation made at least some of the listeners conclude that Jesus had some divine status so that they understood Paul to be a preacher of foreign divinities (17:18)? Does this suggest that Paul also spoke of the miracles of Jesus?

12.This literary strategy has been studied by Radi (1975); see also Green (1996:283299).

13.For a summary of early Christian preaching to Gentile audiences, see Schnabel (2004b:1564). The only passage from Acts on which Schnabel draws is 17:22-31. The remaining passages are from Pauline letters. Peter also offers insights, however.

14.At least one person drew some correct conclusions from this initial proclamation This might also apply to the Christians of Lystra, mentioned later in Acts 14:20 and $16: 1 \mathrm{f}$. For the readers of Acts, Paul's words 'Stand upright on your feet!' in Acts $14: 10$ recall Peter's similar command in Acts 3:6f. There the miracle is ascribed to the risen Jesus; Acts 3:12-16.

15.Cf. the brief discussion in Stenschke (1999:204-210).

16.Does the resurrection function as proof that Jesus is the Messiah? Would this suggest that Paul presented Jesus also in Athens as the Messiah?
Acts 17:31 refers to Jesus as a divinely appointed and approved man. Was this emphasis on the humanity of Jesus necessary to combat the misunderstanding that Jesus was some Hellenistic deity? Only the resurrection of a human (obviously not of an immortal being!) could convincingly serve as proof of his divine appointment to serve as a universal judge.

The serious misunderstanding of that initial proclamation led to Paul's speech before the Areopagus-council. Given that some Athenians thought that Paul was proclaiming new deities and because of the whole set-up of his presentation before the Areopagus-council (cf. Winter 1996:71-90) the scope of Paul's speech is not to present the standard version of the gospel (which had been seriously misunderstood!) again. Instead, its scope was to expose and correct the idolatrous mind-set of the audience. If the narrative context is taken seriously, (detailed) references to the biography of Jesus are not to be expected in Acts 17:22-31. It is only at the end of the speech that Paul points out that the divinely appointed and confirmed judge is not the Hellenistic deity the Athenians had thought him to be.

Caution is therefore required when conclusions are drawn from these - what might be called - 'correction-ofmisunderstanding'-speeches. ${ }^{17}$ This is particularly true when scholars note which aspects of the gospel or the biography of Jesus are 'missing', and when conclusions are drawn from these gaps regarding Luke's understanding of the gospel and its relationship to the role of the biography of Jesus.

Lastly, the definition of certain speeches in Acts as 'missionary speeches' is problematic. The following speeches are usually classified as missionary speeches (e.g. by Wilckens 1974): Acts 2:14-39; 3:12-26; 4:9-12; 5:30-32; 10:34-43 and 13:16-38. Other speeches (which might be classified as defence speeches), however, also refer to the biography of Jesus. ${ }^{18}$ After all, the manner of Paul's defence before King Agrippa led to the king's admission: 'In a short time would you persuade me to be a Christian?' (Ac 26:28). Given, therefore, that material on the biography of Jesus in the missionary speeches (in the narrow sense) is limited, we shall also draw on the references to Jesus in the other speeches in Acts. ${ }^{19}$

\section{Jesus in the missionary speeches of Acts}

Rather than examining each of the missionary speeches and the other speeches in Acts for references to the biography of

17.Wilckens (1974) has not included these speeches as missionary speeches.

18.For a convenient survey of the speeches of Acts, see Soards (1994).

19.Our basis is therefore broader than Wilckens (1974), who focuses on the speeches listed above. For a survey of recent issues concerning the missionary speeches, see Korn (1993:215f.). Korn's own quest is to understand 'the significance which the past history of Jesus as a whole as presented in the mission speeches has for the book of Acts and the era after its composition. Does Luke want to describe proclamation with these mission speeches? If that is the case, for which period? For the early community or as a model for his own later time? Does he intend to indicate the standard of Christian proclamation for all ages, or its historical shape in a by-gone age?' (Korn 1993:214). 
Jesus, ${ }^{20}$ we shall use the framework of the biography of Jesus as our point of departure. ${ }^{21}$

In this section, all the references to the biography of Jesus will be gathered together. ${ }^{22}$ Comments on these will follow in the third section of this article, where certain observations will be highlighted and some interpretation of the material offered, particularly when certain emphases appear in more than one aspect of the biography of Jesus.

\section{The origin of Jesus}

On several occasions, Jesus is being identified as coming from Nazareth (2:22; 4:10; 10:38; 26:9; cf. Lk 1:25; 2:4, 39, 52; etc.). ${ }^{23}$ Jesus was from Galilee (13:30); this is where his ministry began (10:3724). ${ }^{25}$ God has brought from David's offspring to Israel a Saviour, Jesus, as he promised (13:2326)..$^{27}$ In this context, Acts also mentions John the Baptist as the herald for Jesus (cf. Lk 3:1-20; 7:18-33; 9:7-9) (cf. Wilckens 1974:101106). The ministry of Jesus began after the baptism that John proclaimed (10:37). ${ }^{28}$ Before Jesus' coming, John had

20 .For a suvey of research, see Bovon (2006). The speeches of Acts are also examined in detail in Schnabel (2004a, 2004b). Schnabel offers a summary of 'The message of early Christian missionaries' (Schnabel 2004b:1562-1568). The section 'God's Redemptive Messianic Revelation' (Schnabel 2004b:1562-1564) consists of a summary of the missionary speeches of Acts $2-13$. It is instructive to compare the early Christian missionary message to the message of later missionaries; see, for example, Padberg (2003:144-218, 244-315, 413-425).

21.This is also the approach taken by Wilckens (1974). He treats the proclamation about Jesus under the following headings (Wilckens 1974:100-178):

John the Baptist (1974:101-106)

The ministry of Jesus before his death (1974:106-109)

Statements on the sentence and death of Jesus (1974:109-137)

Statements on the resurrection of Jesus (1974:137-150)

Statements on the exaltation of Jesus (1974:150-156)

The Christological titles in the speeches of Acts (1974:156-178).

In contrast, Soards (1994:22-133) examines all the speeches of Acts in their narrative sequence and then draws conclusions as to their content and significance. For Soards, the following passages contain 'prominent christological kerygma': 2:22b-24, 33f.; 3:13-15a; 4:10-12, 27f., 29f.; 5:30f.; 7:52f., 56, 59f.; 10:36-38 $13: 23,27,30 ; 26: 23$.

22.For a synopsis of the references to the biography of Jesus, see also Kliesch (1975:77f.).

23.Jesus' geographical origin from Nazareth is not to be overemphasised; the reference probably appears primarily in order to distinguish him from other men named Jesus (cf. G. Schneider, "Inбoṽc. 3. Träger des Namens neben J. von Nazareth', EWNT II, 443f.). Jesus' origin from Nazareth is not addressed as it is in John 1:45f. On Nazareth, see Hengel and Schwemer (2007:280-283).

24.There are numerous references to Galilee or specific places there in Luke's Gospel $(1: 26 ; 2: 4,39 ; 3: 1 ; 4: 14,31 ; 5: 17 ; 8: 26 ; 17: 11 ; 23: 5,49,55 ; 24: 6)$.

25.The long discussion of the ethnic and religious identity of 1st-century Galilee has been laid to rest. There is now a consensus regarding its Jewish nature. For a survey of the debate and the arguments see Chancey (2002); see also Aviam (2007:115132); Hengel and Schwemer (2007:273-280); Ostmeyer (2005:147-170) and Reed (2000). Probably the last scholar really to argue for a thoroughly Hellenized pagan Galilee was Crossan (1991). For the significance of this geographical background see Schröter (2009:36-55). Some proponents of Nazi New Testament scholarship see Schroter (2009:36-55). Some proponents of Nazi New Testament scholarship argued strongly for the Gentile identity of Galilee in order to deny the Jewish identity of their 'Galilean' Jesus. For the issues involved in some discussions of the identity of the inhabitants of Galilee see Deines (2007:43-131). Deines notes: That attempts to adapt Jesus to the present day social, ecclesial, political and other "powers and authorities" still do not want to forgo exegetical foundations for their cases, finally becomes evident in the significance ascribed up to this day to the Galilean origin of Jesus. Up to now, it continues to have heuristic function, very often in the following manner: against the backdrop of a particularly Galilean culture, however defined, the figure of Jesus is constructed in a way that he is severed from Jerusalem and Judea and from the Judaism represented by these designations and becomes an "other" figure."

26. References to David in Luke's Gospel: 1:27, 32, 69; 2:4, 11 (linking Jesus to the house of David and to Bethlehem); 3:31; 6:3; 18:38f.; 20:41-44.

27.The speeches do not mention the supernatural character of the birth of Jesus, which plays a significant role in the Lukan infancy narrative (Lk 1:30-39). However, other than Matthew 1, it does not play a significant role elsewhere in the New Testament either; see Radl (2001:706f.), Pazdan (1993:584-586) and Räisänen (1992:115-119). Neither do the speeches mention the pre-existence of Jesus.

28.Disciples of John the Baptist appear in Acts 19:1-7. proclaimed a baptism of repentance to all the people of Israel (13:25). The reference to John serves to date the beginning of Jesus' public ministry (cf. Lk 3:1f.).

\section{The ministry of Jesus}

References to the ministry of Jesus in Galilee and on the way to Jerusalem are rare (cf. Lk 4:14-9:50; 9:51-19:27): Jesus was 'a man attested to you by God with mighty works and wonders and signs that God did through him in your midst, as you yourselves know' (2:22). ${ }^{29}$ These deeds express and confirm God's approval of Jesus. God was behind his mighty works and signs. Indeed, God worked through Jesus. This aspect of the ministry of Jesus was known in Jerusalem, although the Lukan Jesus did not perform any of these works in Jerusalem. ${ }^{30}$ The expression 'in your midst' therefore refers to the Jewish people.

This aspect of the ministry of Jesus is assumed to also be known to Peter's Gentile audience in Caesarea ('you yourselves know'). ${ }^{31}$ It is in this setting that there appears the only fairly detailed description of the ministry of Jesus in Acts:

... [God] preaching good news of peace through Jesus Christ (he is Lord of all), for you yourselves know what happened throughout all Judaea, beginning from Galilee after the baptism that John proclaimed, how God anointed Jesus of Nazareth with the Holy Spirit and with power: he went about doing good and healing all who were oppressed by the devil ${ }^{32}$, for God was with him. (10:37-39)

If the expression 'preaching good news of peace' were understood as a reference to the proclamation of Jesus himself, it would define Jesus' proclamation as 'good news of peace'. Taken in this way, these words would constitute the only direct reference in Acts to the proclamation and teaching of Jesus (as 'good news of peace'; obviously a dominant theme in Luke's Gospel). ${ }^{33}$ In Acts 10:36, however, it is God who sent the word to Israel, preaching good news of peace through Jesus Christ. Is it God himself preaching the good news of peace through Jesus Christ (a soteriological statement) or is it God preaching through the ministry of Jesus, his Christ, the good news of peace? The latter seems preferable. $^{34}$

29.For a survey of the miracles in Luke's Gospel and their significance see Zimmermann (2013:513-655)

30.With the exception of the 'private' healing in the context of Jesus' arrest (Lk 22:51), cf. also the signs surrounding the death of Jesus (23:44f.)

31.In view of Acts 10, where details of the life of Jesus are given - although some of them were known to the audience - it is noteworthy that no details are given in Acts 13 .

32.The language of euergetism appears only here, it is not used in Luke's Gospe to describe the ministry of Jesus. However, Marshall (2009) argues for different notions of benefaction in Luke $6: 17-38 ; 14: 1-24 ; 22: 14-34$. Exorcisms appear in Luke 4:33-36, 41; 6:18; 7:21; 8:2, 26-39; 9:37-43; 11:14-23; 13:32.

33.Paul's speech before a Christian audience quotes the words of the Lord Jesus: 'It is more blessed to give than to receive' (20:35). Does this agraphon refer to pre- or post-Easter teaching of Jesus or is this Luke's own summary of the teaching of Jesus on material wealth? Paul had proclaimed the 'whole counsel of God' (20:27) which will have included all of Jesus' life, God's purposes with him, and the salvation to Jews and Gentiles.

34.See the discussion in Barrett (1994:521f.). 
Reminiscent of the portrayal of Jesus in Luke's Gospel, Peter's sermon further describes:

- the geographical scope of the ministry of Jesus (all Judaea, beginning from Galilee $)^{35}$

- a chronological reference ('after the baptism that John proclaimed'), which is possibly also a temporal reference within the framework of salvation history ${ }^{36}$

- God's empowerment of Jesus with the Holy Spirit and divine power (cf. Luke 3:21f.; 4:18-21)

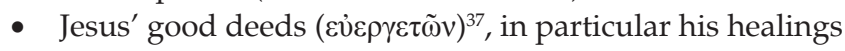
and exorcisms ('healing all who were oppressed by the devil')

- the emphasis that in all this God was with Jesus (cf. 2:22)

- Peter and other disciples of Jesus are the witnesses of 'all that Jesus did both in the country of the Jews and in Jerusalem' (39; cf. Lk 19:28-24:51). ${ }^{38}$

Jesus is presented as the climax of God's saving story of Israel (Ac 13:23): 'Of David's offspring God has brought to Israel a Saviour, Jesus, as he had promised.' It is also mentioned that Jesus had gathered a following. After his resurrection, 'Jesus appeared to those who had come up with him from Galilee to Jerusalem' (13:31). Their witness plays a crucial role.

The proclamation of the kingdom of God and/or other teaching of Jesus are not given directly. ${ }^{39}$ In addition, apart from one summary reference to Jesus' deeds in Acts 10:39 and Jesus' 'doing good', only one aspect of God's 'mighty works and wonders and signs through Jesus' (2:22), namely, the exorcisms are explicitly mentioned ('healing all who were oppressed by the devil')..$^{40}$ The twelve disciples or apostles are not explicitly mentioned. ${ }^{41}$ Wolter (2008) notes:

Details of the Lukan account of Jesus appear in contrast in Acts only rarely. This applies mainly to the teaching of Jesus. While Acts 13:25 and 19:4 quote the words of John the Baptist from Luke 3:16 or refer to it, there is not a single word of Jesus from Luke's gospel that would be quoted or alluded to in Acts (the word of Jesus which is quoted in 11:6, comes from Acts 1:5).

35. In this ministry in all of Judaea, the re-gathering and restoration of Israel took place. Judea is mentioned in Luke $1: 5,65 ; 2: 4 ; 3: 1 ; 4: 44 ; 5: 17 ; 6: 17 ; 7: 17 ; 21: 21$; 23:5.

36.Some scholars argue that the reference serves to place John in relation to Jesus in Luke's salvation historical perspective; once the ministry of John, the greatest prophet of the old covenant had been completed, Jesus began with his ministry; this is what some scholars, in the wake of Conzelmann (1964), have argued regarding the chronological sequence in Luke 3, which avoids an overlap of the ministries of John and of Jesus as in John's Gospel.

37.It is noteworthy that this aspect of the ministry of Jesus is singled out as an example of $\varepsilon \dot{\varepsilon} \varepsilon \rho_{\varepsilon} \tau \tilde{\omega} v$; for the background and significance of the language of euergetism in

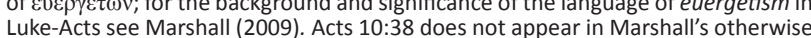
instructive treatment. This Hellenistic technical term for relationships of reciprocity occurs only before a Gentile audience (the ministry of Jesus is hardly addressed occurs only beft.
elsewhere).

38.See Acts $14: 9$ as an indirect further reference to the healing ministry of Jesus.

39.The kingdom of God is implied in the summary of Acts 10:38. It is also implied in every reference to Jesus as the Messiah or Christ. According to Acts 8:12, Philip preached the good news about the kingdom of God and the name of Jesus Christ. Christ and the kingdom are closely linked. For the close relationship between the Christ and the kingdom of God, see Stuhlmacher (2005:65-74).

40.This is the only reference to the devil in the missionary speeches of Acts (cf. Ac 26:18). Luke 22:3 identifies the devil as one of the driving forces behind the passion and death of Jesus. On several occasions, Gentiles are associated with the devil (Lk 4:5f.; Ac 16:16; 26:17f.; cf. Stenschke 1999:244-264; 381f.; cf. also Garrett 1989).

41.Peter and the Eleven appear as giving the missionary speech of Acts 2 together (2:14).
... Of the narrative sections of Luke's gospel (other than the vague reference to Luke 3:22 in Acts 4:27 - 'your holy servant, whom you have anointed') only events from the passion and resurrection narratives are referred to in Acts ... (p. 31 $)^{42}$

Some scholars have suggested that these aspects of the biography of Jesus are not or are no longer important because they all have been eclipsed by the supreme importance of the resurrection of Jesus. The primary function of these few references is to prove that Jesus was the agent of God.

\section{The passion, death and burial of Jesus}

- The passion and death of Jesus are more prominent aspects of the biography of Jesus in the speeches of Acts (cf. the Lukan passion narrative, Lk 22:1-23:56). Jesus was crucified and killed at the hands of 'lawless men' (2:23, Lk 23:1-52), that is, by Gentiles (anomoi)..$^{43}$ At the same time the involvement of some Jews of Jerusalem is emphasised: ${ }^{44}$ this Jesus whom you crucified ... (2:36, cf. Lk 23:21?)

- they delivered over and denied Jesus in the presence of Pilate, when he had decided to release him. In doing so, they denied (not only their fellow Jew, but) the Holy and Righteous One 'and asked for a murderer to be granted to you, and you killed the Author of life ...' (3:13, cf. Lk 23:1-5, 13-23, several allusions)

- Jesus Christ of Nazareth, whom you crucified (4:10)

- Jesus is the stone that was rejected by you, the builders $(4: 11)$

- ... whom you killed by hanging him on a tree (5:30)

- the Righteous One, whom you have now betrayed and murdered (7:52).

In references to the death of Jesus outside of Jerusalem, the second person plural references to the protagonists ('you') change to third person plural pronouns or nouns: '... of the Jews and in Jerusalem. They put him to death by hanging him on a tree' (10:39, in Caesarea) or:

For those who live in Jerusalem and their rulers, ... by condemning him. And though they found in him no guilt worthy of death, they asked Pilate to have him executed. And when they carried out all that was written of him, they took him down from the tree and laid him in a tomb. (13:27-29, speech delivered by Paul in Pisidian Antioch)

In this passage it is noteworthy that the referent of the third person plural pronouns changes without indication: from the inhabitants of Jerusalem and their rulers to Joseph of Arimathea and the disciples of Jesus. ${ }^{45}$ Other than this 42.Wolter dismisses Acts 20:35 too easily.

43.Pilate is mentioned repeatedly later on: $3: 13 ; 13: 28$. The prayer of the church in Acts 4:26-28 refers to the plot against Jesus by 'both Herod [Antipas] and Pontius Pilate, along with the Gentiles and the peoples of Israel'.

44.This is confirmed by the perception of this aspect of the Christian proclamation by the religious leaders in Jerusalem mentioned in Acts $5: 28:$ '... you intend to bring this man's blood upon us'. On the Jewish involvement in the death of Jesus, see Weatherly (1994), who corrects the one-sided perspective by Sanders (1987). On all issues concerning Israel and the Jews in Luke-Acts, Jacob Jervell has opened
new venues and has rightly questioned much previous research on the theme; for summaries see Jervell $(1996,1998)$.

45.The disciples do not appear in the account in Luke 23:50-54, which presents the burial of Jesus as the sole activity of Joseph. 
summary, the details of the rejection and death of Jesus (if they should be expected in this abbreviated account of the speech and the events and in view of the detailed account in Luke's Gospel) are not a major concern.

In the context of the Jewish involvement in the death of Jesus, it needs to be remembered that, in the speeches in Acts, Jews are pictured as addressing fellow Jews concerning the Jewish involvement in the death of Jesus the Jew. That is their main concern. Throughout Acts, Jewish Christians are speaking. The readers of Acts are listening in to an inner-Jewish debate. This accounts to some extent for the Jewish character of the speeches and of their presentation of the biography of Jesus, including his rejection and death. The New Testament provides little information as to how Gentile Christians would have presented the gospel (including the human involvement in the death of Jesus) to Jews and Gentiles.

Acts 13:29 is the only reference to the burial of Jesus which emphasises the fact of his death (cf. Lk 23:50-56).

Rather than providing an in-depth soteriological interpretation of the salvific nature of the death of Jesus (which some scholars expected to be Luke's main concern; see what follows), Luke emphasises instead that the suffering and death of Jesus happened according to the purpose and plan of God. ${ }^{46}$ These events all happened in fulfilment of Scripture (cf. the theme in Lk 22:37; 24:26f., 44-47):

- Jesus was delivered up according to the definitive plan and foreknowledge of God (2:23)

- that the Christ would suffer was foretold by God by the mouth of all the prophets $(3: 17)$

- to do whatever your hand and your plan had predestined to take place $(4: 28)^{47}$

- ... because they did not recognise him nor understand the utterances of the prophets, which are read every Sabbath (and therefore were known), fulfilled them by condemning him ... And when they carried out all that was written of him (13:27-29)

- that the Christ must suffer and that, being the first to rise from the dead, he would proclaim light to our people and to the Gentiles (26:23).

As a suffering and executed Messiah was not - or at best only a minor - part of early Jewish Messianic expectation, ${ }^{48}$ this

46.The interplay between human responsibility and guilt and the fulfilment of the plan of God is not resolved in Acts.

47.Acts 8:32 quotes Isaiah 53:7f. Later, Philip begins with this Scripture and tells the eunuch the good news about Jesus $(8: 35)$. This would have included the suffering, death and resurrection of Jesus. This is not made explicit, however. In Acts 8:32f the manner of the suffering and death of Jesus is in view, not its salvific significance as in Isaiah 53:4-6 and its reception in early Christianity; cf. Mittmann-Richert as in Isaiat
(2008).

48.The diversity in early Jewish eschatological expectations must be noted and has been emphasised in recent scholarship. The extant sources (howeve representative they may be!) indicate that not everyone awaited a Messiah or single messianic figure, however defined. It seems clear, however, that for few of those expecting a messianic figure, his ministry would include suffering and death For surveys and discussions of early Jewish eschatology, see Chester (2006), Henge and Schwemer (2007:161-168), Karrer (1990), Oegema (1994, 2008:406-409) and Porter (2007). According to Oegema (2008:406), messianic texts are texts 'from Porter (2007). According to Oegema (2008:406), messianic texts are texts from the Hebrew Bible or the early Jewish and Christian tradition, in which the coming of a Davidic priest and/or king is expected, who has been promised to Israel, who is filled with the Holy Spirit and who will free the people of God from the nation of the world at the end of time and rule over them with justice and peace. Thus, a Messiah is a priestly, royal, or otherwise characterized figure, which will play a liberating role at the end of days'. For Jesus as the Messiah of Israel see Hengel (2003:1-80) aspect of the biography of Jesus was in particular need of explanation before Jewish audiences.

Although the missionary speech before Gentiles in Caesarea gives the most detailed account of the ministry of Jesus (see the previous), his death and its particular circumstances are mentioned so briefly that they can hardly be understood:

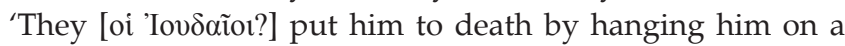
tree' (10:39). Before this Roman audience $(10: 1,22,24)$, Jesus was killed 'by hanging him on a tree' (10:39). ${ }^{49}$

The innocence of Jesus ('and though they found in him no guilt worthy of death', 13:28) and the involvement of the Roman governor Pilate are mentioned only in a speech away from Jerusalem, in Pisidian Antioch ('they asked Pilate to have him executed', 13:28).

\section{The resurrection of Jesus ${ }^{50}$}

The resurrection of Jesus is the most prominent feature of the biography of Jesus in the missionary speeches of Acts (cf. Lk 24, but also 9:22; 18:33). ${ }^{51}$ Wolter (2008) writes:

In his account of the Christ-proclamation of the witnesses, Luke places the resurrection above all other events at centre-stage (see Acts $1: 22 ; 4: 2,33 ; 10: 40 f ; 17: 18,31 ; 24: 21)$. The reason for this is that the resurrection is foundational for the special character of the messianic reign of Jesus: through it Jesus sits on 'the throne of his father David and will reign over the house of Jacob in all eternity and that to his reign there will be no end' (Luke 1:32f). (p. 32)

In almost every occurrence, the emphasis is on God's activity in the resurrection (not in Luke's Gospel):

- God raised Jesus from the dead (2:24)

- this Jesus God raised up (2:32)

- whom God raised from the dead (3:15)

- God, having raised up his servant (3:26)

- whom God raised from the dead (4:10)

- the God of our fathers raised Jesus (5:30)

- but God raised him on the third day and made him to appear not to all the people but to us who had been chosen by God as witnesses, who ate and drank with him after he rose from the dead (10:40)

- but God raised him from the dead, and for many days he appeared to those who had come up with him from Galilee to Jerusalem (13:30)

- ... what God had promised to the fathers, this he has fulfilled to us their children by raising Jesus, as it is written (13:32; this is summarised as 'the good news')

- and as for the fact that he raised him from the dead, no more to return to corruption (13:34)

- but he whom God raised up did not see corruption (13:36)

- Paul preached Jesus (and presumably also his death) and the resurrection in Athens (17:19) and returned to both

49.The cross is not mentioned at all in Acts, however; the verb "to crucify" appears only twice $(2: 36 ; 4: 10)$. The exact circumstances of the death of Jesus apparently do not play a prominent role.

50.Cf. Talbert (1992:19-30) and Anderson (2006).

51.The apostles are said to be proclaiming in Jesus the resurrection of the dead $(4: 2)$. Paul was preaching Jesus and the resurrection in Athens (17:19). 
these themes when he spoke about God's appointed universal judge, of whom God has given assurance to all by raising him from the dead (17:31). ${ }^{52}$

Jesus was the first to rise from the dead, and was the person who would proclaim light to Israel and to the Gentiles (26:23). This proclamation would happen through the mission to both Jews and Gentiles.

There is only one reference to a longer period of resurrection appearances (13:30; cf. 1:3; different in Luke's Gospel) and to the bodily nature of the resurrection of Jesus ('who ate and drank with him', 10:40, cf. Lk 24:29-31, 41-43). ${ }^{53}$

As far as the resurrection of Jesus is concerned, the role of the disciples as witnesses is emphasised (cf. Lk 24:48): 'We are witnesses to these things, and so is the Holy Spirit' (5:32); '... and for many days he appeared to those who had come up with him from Galilee to Jerusalem and who are now his witnesses to the people' (13:30). Their witness confirms the resurrection as a real event in the recent past in time and space.

Closely related to the role of the disciples as witnesses of Jesus' resurrection is their commission for mission (Lk 24:47-49): the risen Jesus charged the disciples to preach to the people and to testify that he is the one appointed by God to judge the living and the dead (10:42). ${ }^{55}$ The mandate of witness also extends to other Christians (Paul and Barnabas): 'we are now his witnesses to the people' (13:30) and its scope also includes Diaspora Jews and God-fearers (13:16). ${ }^{56}$

In his ministry and death, Jesus had been a public figure (from Lk 4:14 onwards; 'as you yourselves know what happened throughout all Judaea', 10:37; 26:23: 'For the king knows about these things ... For I am persuaded that none of these things has escaped his notice, for this has not been done in a corner'). This phase of his life did not require special witnesses. But because it was open to different interpretations (cf. Lk 11:14-23), the Christian proclamation left no doubt as to what to make of all that had happened ('God had anointed Jesus and was with him', 10:38).

52.Korn (1993:217) observes that the resurrection has a key position in the Areopagus speech and notes: 'In a similar manner, Luke can also in Acts 1:21f focus the witness of the Twelve on the resurrection, although their testimony comprises the entire of the Twelve on the resurrection, although their testimony comprises the entire ministry of Jesus from his baptism to his ascension'. Korn describes the significance of the resurrection in this speech in some detail. If Korn is to be followed in that the references to the resurrection refer to the entire ministry of Jesus from his baptism to his ascension', then the public ministry of Jesus is far more present in the missionary speeches than few direct references might otherwise suggest. If the mention of the resurrection in Acts 17:18f. functions as proof for Jesus the Messiah, this would imply that Paul presented Jesus as the Messiah also in Athens. Acts 22:6-11 also presupposes that Jesus is alive. As such, he could appear to Paul on the road to Damascus and later on in the temple in Jerusalem (22:17-21).

53.This appears before a Gentile audience (cf. Lk 9:7-9; Ac 17:32; 26:23f.); was the bodily nature of the resurrection assumed as obvious before Jewish audiences?

54.Their witness here also includes the exaltation of Jesus: 'God exalted him at his right hand as Leader and Saviour, to give repentance to Israel and forgiveness of sins.'

55.Their witness is supplemented by the witness of the prophets (10:43; cf. Lk 24:27, 44f.).

56.Their witness is supported by the Lord himself, who bore witness to the word of his grace, granting signs and wonders to be done by their hands (14:3).

\section{The exaltation, present ministry and parousia of Jesus}

In the speeches of Acts the portrayal of Jesus moves beyond the resurrection and ascension. ${ }^{57}$ To what extent the references to the exaltation, present ministry and the parousia of Jesus should still be considered an integral part of the biography of Jesus is disputable and a matter of definition. For obvious reasons, the current broad discussion on the nature and significance of 'biography' does not address this issue. ${ }^{58} \mathrm{~A}$ distinction between the earthly Jesus and the Christ of faith might be helpful for the purposes of scholarly discussion, but does not do justice to the portrayal of Jesus in Acts. Acts stresses a progressive continuity. It is the same Jesus whose role and significance increase as the story unfolds.

Firstly, the exaltation of Jesus is mentioned as the climax of God's approval of Jesus as the Christ: 'Jesus was exalted and having received from the Father the promise of the Holy Spirit, he has poured out this ...' (2:33). God made him both Lord and Christ (2:36). In continuity with the history of Israel, the God of Abraham, the God of Isaac and the God of Jacob, the God of our fathers glorified his servant Jesus (3:13). God exalted Jesus at his right hand as Leader and Saviour (5:31). As a result of his exaltation, Jesus Christ is Lord of all (10:36).

Secondly, the present activities of the exalted Jesus are a prominent feature of the speeches and narrative parts of Acts. Speeches: Jesus poured out the Holy Spirit on the disciples a few days after his ascension (2:33). After the resurrection (and ascension, 3:21), God sent Jesus first to the Jews (the people of Jerusalem?) to turn them from their wickedness (3:26)..$^{59}$ The exalted Jesus is still actively involved: '... whom God raised from the dead - by him this man is standing before you well' (4:10; cf. also 3:16: 'And his name - by faith in his name has made this man strong ...'). 'God exalted Jesus at his right hand as Leader and Saviour to give repentance to Israel and forgiveness of sins' (5:31). Through Jesus forgiveness of sins is proclaimed and by him everyone who believes is freed from everything from which they could not be freed by the Law of Moses (13:38f. - does this refer to the present ministry of Jesus or back to his death?). ${ }^{60}$ Being the first to rise from the dead, Jesus would proclaim light both to our people and the Gentiles (26:23). The mission of the church (as 'proclaiming light') to Jews and Gentiles is presented as an activity of the risen Jesus. The ongoing mission of the church can be understood as a part of the biography of Jesus.

In addition, there are narrative reports of the present activities of the exalted Jesus: God is asked to stretch out his hand to heal and for signs and wonders to be performed through the

57.Cf. Luke 24:50f.; 1:32f.; Luke 9:26 refers to the future coming of the Son of Man in glory. For the eschatology of Luke's Gospel see Wolter (2011:91-108); for the eschatology of Acts see Busse (2011:141-178) and Schaefer (2012).

58.For recent discussion, see Klein (2009).

59.This happens through the apostolic preaching; the ministry of the risen Jesus is limited to the disciples (1:2f.).

60.Jews and Gentiles are saved through the grace of the Lord Jesus (15:11, in a speech to Christians), Does this support Wolter's thesis, namely that crucial soteriological statements in Acts are restricted to inner-Christian catechesis? 
name of his holy servant Jesus (4:30). Stephen sees Jesus or the Son of Man standing at the right hand of God and addresses him in prayer as Lord (7:56, 59f.). He is the one who receives Stephen's spirit and who forgives the sin of those who kill Stephen. Jesus appears to Paul and commissions him (9:3-6; 22:7-10; 26:12-18). Jesus also appears and speaks to Ananias (9:10-16). Peter says to Aeneas: 'Jesus Christ heals you' (9:34). The Lord (is this a reference to Jesus?) bears witness to the word of his grace, granting signs and wonders to be done by the missionaries (14:3). In at least one instance, the Spirit of Jesus directs the course of a missionary journey (16:7). Paul exorcises a demon in the name of Jesus (16:18). The Philippian jailer is called to believe in the Lord Jesus and then he will be saved by him (16:30). Jesus appears to Paul also in the temple of Jerusalem and commissions him (22:18-22). After his rejection by the Jewish people in Jerusalem, the Lord stands by Paul: 'Take courage, for as you have testified to the facts about me in Jerusalem, so you must testify also in Rome' (23:11).

Luke's statements about the exaltation of Jesus and his ministry as the exalted Christ derive from royal messianic Christology, which interprets the exaltation of Jesus as his enthronement as Messiah and as a sign of highest divine approval and appreciation of his person and ministry. Luke has integrated them into his presentation of Jesus on the premise that Jesus was God's Messiah from the beginning (Lk 1:32f., 43, 68-79; 2:11, 30-32) and before his death, resurrection and exaltation. For Luke, the exaltation of Jesus represented a particular and new 'stage' in the biography of Jesus. There was not a point in time before which Jesus was not Messiah or Son of God. ${ }^{61}$

Lastly, the parousia and future tasks of Jesus are also mentioned: 'that God may send the Christ appointed for you, Jesus, whom heaven must receive until the time of restoring all things' (3:20, to what extent Jesus is involved in the restoration is not clear; cf. Lk 9:26f.). Jesus will be sent by God as the appointed Christ for Israel; this will lead to the restoration of all things. Jesus is appointed by God to judge the living and the dead (10:42). Divine judgement will be effected through a man whom God has appointed and of this God has given assurance to all by raising him from the dead (17:31).

61.For a survey, see Schweizer (1989). For the significance of the Old Testament, in particular of Psalm 110 for exaltation Christology, see Hengel (1995a:119-225); see also Eskola (2001) and Lee (2005). In his study, 'Christology and Transformation', Chester (2006:13-121) surveys and examines recent arguments for Christ as divine from the beginning and then studies intermediary figures and human transformation in early Jewish sources (logos and wisdom, angelic figures, exalted human figures) and applies this to New Testament Christology. Chester argues that the phenomenon of earliest Christology can only be understood as developing within a Jewish context, and that Jewish intermediary figures constitute a central within a Jewish context, and that Jewish intermediary figures constitute a central
and integral part of that context' (Chester 2006:119). According to Chester, 'early
Christian visionary experiences of the resurrected Jesus, as transformed and set Christian visionary experiences of the resurrected Jesus, as transformed and se
alongside God in the heavenly world, are crucially important for the development alongside God in the heavenly world, are crucially important for the development achieve this effect in combination with what is known otherwise of Jesus: his proclaiming of the kingdom of God, his inaugurating of this, especially in his healing and exorcising, and the intimate relationship of sonship with God that he had claimed to have. It is, then, this whole understanding of how Jesus had made himself known distinctively through his activity and through his life and made himself known distinctively through his activity and through his life and death, bound up with the deeply-held conviction that he had been raised from the dead, and combined also with the visions and traditions of him having been seen in transformed mode alongside God in the heavenly world, that allowed or ( with God himself. The subject is also addressed in Chester's study 'Resurrection, Transformation and Christology' (Chester 2006:123-190; see also Avemarie \& Lichtenberger 2001).

\section{Narrative portrayals of Jesus}

In addition to these references from the speeches of Acts, there are some narrative reports of how the early Christians spoke of (the biography of) Jesus. They are mentioned here for the sake of completeness. Obviously these narrative reports and titles also allude to the presentation of Jesus in Luke's Gospel. The majority of these references occurs in the later chapters of Acts and are predominantly titular: Philip proclaimed the Christ to the Samarians (8:5). Paul proclaimed Jesus in the synagogues of Damascus, saying 'He is the Son of God' and proved that Jesus was the Christ $(9: 20,22)$. In Thessalonica:

Paul reasoned with them from the Scriptures, explaining and proving that it was necessary for the Christ to suffer and to rise from the dead, and saying: This Jesus, whom I proclaim to you, is the Christ. $(17: 3)^{62}$

Paul testified to the Corinthian Jews that 'the Christ was Jesus' (18:5). Apollos taught accurately the 'things concerning Jesus', probably including some aspects of his life (18:25). In Achaia, Apollos powerfully refuted the Jews in public, 'showing by the Scriptures that the Christ was Jesus' (18:28). ${ }^{63}$ Paul summarises his ministry as 'testifying both to Jews and Greeks of repentance toward God and of faith in our Lord Jesus Christ' (20:21). Felix heard Paul speak about faith in Christ Jesus (24:24). Festus summarises the dispute between Paul and his fellow Jews as 'about a certain Jesus, who was dead, but whom Paul asserted to be alive' (25:19). Paul tried to convince the leading Jews of Rome 'about Jesus both from the Law of Moses and from the Prophets' (28:23). In Rome Paul taught about the Lord Jesus Christ (28:30).

These references to Jesus raise the question of the relationship between the presentation of the biography of Jesus in the 'missionary' speeches, in other speeches and in the narrative sections of Acts. Whilst there is variation in detail, there are no major differences between these different presentations. Most narrative references use Christological titles which embody what the speeches (and obviously Luke's Gospel) present in more detail.

\section{Interpretation of the biography of Jesus in the missionary speeches of Acts}

When conclusions are drawn from this evidence, the introductory observations need to be remembered, that is, Acts is part two of a two-volume work and its author presupposes that the readers have read volume one, which is devoted to the biography of Jesus from the annunciation of his birth to his ascension (24:51). In addition, some of the aspects of the biography of Jesus are claimed to be known

62.Paul's Jewish opponents in Thessalonica charge him with 'acting against the decrees of Caesar, saying that there is another king, Jesus' (17:7). What implications may be drawn from these charges about the actual proclamation of Paul? Did Paul speak about the reign of God and the pivotal role of Jesus in its inauguration, present development and eschatological consummation? His message in Rome is present development and eschatological consummation? His message in Rome is
summarised as '... proclaiming the kingdom of God and teaching about the Lord summarised as '... prod
Jesus Christ' (28:31).

63.The centrality of Jesus in the preaching of Paul is indirectly attested by some Jewish exorcists, who adjure demons 'by the Jesus whom Paul proclaims' (19:13). 
to the audience of the missionary speeches in Jerusalem and Caesarea. Thus, there was no need for repetition. With these limitations in mind, some observations may be highlighted.

\section{Emphases in the presentation of Jesus in the missionary speeches of Acts}

In addition to his biography up to his resurrection and exaltation, Jesus is presented as still being active during the narrative of Acts (see the aforementioned), and his future involvement beyond the end of Acts (28:31) is predicted. In other words, the biography of Jesus in Acts is open-ended, although it is clear what, or better, whom the future will bring. In these references to the biography of Jesus, there are several noteworthy features.

\section{The saving significance of all of Jesus' biography}

Whilst there is an emphasis on the death and resurrection of Jesus, his whole life is of importance. In his death and resurrection, but also in his entire ministry, Jesus of Nazareth was and is God's Christ and Saviour. Korn (1993) rightly observes as follows:

Finally, the variation of the proclamation of Jesus in the different speeches emphasises that, ultimately, the entire story of Jesus is the foundation of salvation. Whilst individual motives may vary in the presentations, the proclamation concerns the offer of salvation which became available through the whole of Jesus' ministry. (p. 225, emphasis added)

Salvation is to be found in no one else but Jesus (4:12) - this exclusive claim is not limited to one episode or aspect of the biography of Jesus.

In view of the present and future significance of Jesus, Korn's focus on 'the past history of Jesus' is questionable. This focus falls short of Korn's own study, which includes the resurrection of Jesus (Korn 1993:185-189, 259-269). The resurrection implies the question of what became of the resurrected Jesus. The present and future biography of Jesus is as much part of the presentation of Jesus as the Jesusevent of the past. The manner in which Jesus is mentioned in Acts (in missionary speeches and elsewhere) clearly speaks against the idea that, through the book of Acts, the divine mission of salvation to Israel as told in Luke's Gospel becomes 'something completely in the past, history indeed' ${ }^{64}$ Wolter (2008) notes:

What Luke has done is not non-theological 'history' according to the understanding of Käsemann because in his summary references to the whole story of Jesus, Luke always interprets the ministry of Jesus from a distinctly theological perspective: it is God himself who has acted in the ministry of Jesus to Israel for salvation. God is represented by Jesus in an authentic manner. (p. 31f.)

Peter's speech in Caesarea is summarised as the 'word of the gospel' (Acts 15:7) as follows: 'Since its content is essentially the story of Jesus Christ, it is this story which is called "gospel"' (Korn 1993:223). Korn also notes Acts 13:32 ('And we bring you the good news that what God promised to the fathers ...'): 'through this the following account of Jesus Christ is designated as the content of this proclamation of the gospel'. The gospel and the whole biography of Jesus are therefore inseparably linked.

It has often been noted that, beyond a mere contrast (see e.g. P. Stuhlmacher) ${ }^{65}$ no interpretation of the death of Jesus on the cross as an atoning sacrifice or the like is offered by the missionary speeches or other sections of Luke-Acts. The only statements that somewhat explain the death of Jesus in its salvific significance appear in Luke 22:19f. and Acts 20:28. ${ }^{66}$ This had been noted in particular in earlier German research, when Lukan theology was compared with a certain type of understanding of Pauline soteriology, in particular the significance of the cross in Kreuzestheologie (theology of the cross). ${ }^{67}$ In the heyday of Paul's 'theology of the cross', when it was considered the only legitimate expression of Protestant (existentialist) theology, Luke was charged with not reaching the 'depth' of Paul's understanding of the death of Jesus. ${ }^{68}$ Despite major changes in the assessment of Lukan (and Pauline!) theology, this view still finds proponents. However, it needs to be added that the position has been argued recently in a more nuanced manner; see, for example, H.J. Sellner's recent Das Heil Gottes: Studien zur Soteriologie des lukanischen Doppelwerkes. ${ }^{69}$

In addition to our previous argument that the entire biography of Jesus is of saving significance in Luke-Acts (which has often been noted) ${ }_{1}^{70}$ other observations deserve to be mentioned. In her monograph, Der Sühnetod des Gottesknechts: Jesaja 53 im Lukasevangelium [The Propitiating Death of the Servant: Isaiah 53 in the Gospel of Luke] (2008), U. Mittmann-Richert has argued in detail that, whilst Luke does not use certain Pauline words or concepts, his understanding of the death of Jesus is distinct in Luke's Gospel and not lacking in any depth when compared with other New Testament witnesses. In his ministry and in his death, Jesus is portrayed as the

65.Pichler (1997:63): 'The smallest common denominator of the missionary speeches is the contrast between human activity (the statements regarding the killing of Jesus) and God's activity (statements regarding the raising or resurrection of Jesus)'; see Pichler's discussion (1997:64-71) and Stuhlmacher (2005:190).

66.For surveys of research, see Sellner (2007), Mittmann-Richert (2008:1-54) and Böttrich (2005:413-436). Böttrich notes, 'Luke the evangelist is no outsider in the NT when it comes to a soteriological understanding of the death of Jesus. .. However, he does not consider the death of Jesus as the controlling centre point, from which the entire soteriology should be unfolded in a dogmatic manner. In the entire narrative context the death of Jesus has a firm in ace, without becomin the entire narrative context the death of Jesus has a firm place, without becoming the dominating feature' (Böttrich 2005:435). On the differences between Luke and Paul, Böttrich astutely observes the following: 'Their different emphases are due to different perspectives, which derive from the logic, with which both authors pursue their literary strategies: Paul's argumentation requires concentration of the issues while Luke's presentation is characterised by the richness of aspects of
biographical narration' (Böttrich 2005:436).

67.For a summary, see Dettwiler and Zumstein (2002).

68.For a survey and critical assessment of this position, see Mittmann-Richert (2008).

69.Sellner's (2007:403-480) first section in his chapter on the salvific nature of the death of Jesus is called 'Vom Kreuz keine Spur' ('Not a trace of the cross'; Sellner 2007:403-405). This headline is at best ambiguous in view of the references to the cross of Jesus in Luke's Gospel and to him being crucified in the missionary speeches of Acts. The cross is not interpreted in the same manner as elsewhere in the New Testament.

70.Acts 7:52 sets the rejection of Jesus in the long line of rejections of God's earlier agents, as follows: 'Which of the prophets did your fathers not prosecute? And they killed those who announced beforehand the coming of the Righteous One, they killed those who announced beforehand the coming of the Righteous One,
whom you have now betrayed and murdered' (cf. Lk 13:31-33); see Stenschke (1996:123-148) and Steck (1967). 
suffering servant of Isaiah. Traces of this understanding can

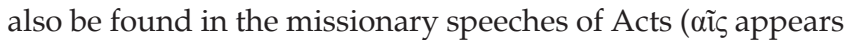
in Ac $3: 13,26 ; 4: 27,30){ }^{71}$

\section{Wolter (2008) also notes:}

The explanation for the lack of the concept of propitiation in the missionary speeches of Acts is that the interpretation of the death of Jesus as salvific was an element of early Christian inner community-language, which would have been completely misplaced in the missionary speeches. ${ }^{72}$ (p. 9)

It should also be noted that only a few aspects of the biography of Jesus in the missionary speeches in Acts are interpreted with any 'theological depth', be it Pauline or otherwise; for example, the sending or birth of Jesus as incarnation. The only interpretation that is offered regularly is that God was behind the various aspects of the biography of Jesus (e.g. Ac 2:22: 'a man attested to you by God with mighty works and wonders and signs that God did through him ...'; 10:37f.). In a sense, Luke is profoundly theological (see below). What transpired happened in fulfilment of the will and plan of God.

A full debate of Lukan soteriology is beyond the scope of this article. The portrayal of Jesus in the missionary speeches and the saving significance of all of this life - past, present and future - offers correctives to a one-sided focus on the death of Jesus. In his entire biography Jesus is God's Saviour for Israel and the nations. This life includes his supernatural miracles, his resurrection, ascension, exaltation and parousia. ${ }^{73}$

\section{The fulfilment of Scripture in the biography of Jesus}

In addition to emphasising the witness of the disciples (in particular of the resurrection of Jesus, see the aforementioned) ${ }^{74}$ the witness of the Scriptures to Jesus plays a crucial role: ${ }^{75}$ Jesus is portrayed as the prophet predicted by Moses (3:22f.). 'And all the prophets who have spoken, from Samuel and those who came after him, also proclaimed these days' (3:24). 'To Jesus all the prophets bear witness that

71.In her study of Luke's Gospel, Mittmann-Richert announces a forthcoming study in which she will trace the motif in Acts (Mittmann-Richert 2008:314).

72.Wolter (2008) notes, 'Finally, also the so-called concept of propitiation is neithe "typically Jewish" (see only Versnel, Making Sense), nor is it alien to Luke, as is indicated by Luke 22:19f and Acts 20:28'; see also Wolter's discussion of Luke 22:19. Wolter (2008:704f.) refers to Versnel (2005:215-294); see also Wolter's essay, 'Der Heilstod Jesu als theologisches Argument' (2005:297-313) and Van Zyl (2002:533557). Wolter (2008:705) argues as follows: 'One should be and Van Zyl (2002:533557). Wolter (2008:705) argues as follows: 'One should be very cautious to claim that the concept of propitiation was receding (e.g. Schnelle, Einleitung, 286 fo many other authors). To be sure, Luke did not take over the ransom saying from Mark 10:45, nevertheless, scholars miss the interpretation of the death of Jesus as a salvific death in the missionary speeches of Acts without good reason, because this interpretation is a theologuomenon of inner-Christian discourse.' Wolter refer to Schnelle (2007). The reference to 'the church of God, which he obtained with his own blood' (Ac 20:28) appears in a speech before a Christian audience!

73.Was the focus on the death of Jesus theologically so attractive to a previous generation of scholars (at the height of rationalism in the 1960s and 1970s!), because it played down or excluded the significance of supernatural events in the life of Jesus? Has Luther's theologia crucis had a similar impact on Lukan studies as his teaching on justification had on Pauline studies? Luther's real and/or alleged influence on (mainly German) Pauline studies has been emphasised by the 'new perspective' on Paul. Luther's indirect influence on Lukan studies - via Pauline studies - has not been examined in detail.

74.For the witness-motif in Acts, see Soards (1994:192-194, 197-200).

75.Soards (1994:187-189) speaks of 'The operation of God's plan'; see Squires (1993) and Bock (1998:19-39); for surveys of Luke's use of the Old Testament see Bock (1987) and Rusam (2003). everyone who believes in him receives forgiveness of sins through his name' $(10: 43){ }^{76}$

This motif of fulfilment of the Scriptures or the will of God in the biography of Jesus is a particular feature in Acts 13: Of David's 'offspring God has brought to Israel a Saviour, Jesus, as he promised' (23). The inhabitants of Jerusalem and their rulers fulfilled the well-known utterances of the prophets by condemning Jesus (27). 'All that was written of him' had been carried out in the rejection and execution of Jesus (29). The Christian proclamation is the good news 'that what God had promised to the fathers, this he has fulfilled to us their children by raising Jesus, as also it is written in the second psalm' .... Concerning the resurrection of Jesus ('And as for the fact that he raised him from the dead, no more to return to corruption', 34) God had spoken in this way, 'I will give you the holy and sure blessings of David' (34). Therefore God says (of the resurrection) 'also in another psalm' (13:35). The warning in Acts 13: 41 also comes through a word from the prophets (Hab 1:5): '... for I am doing a work in your days, a work that you will not believe, even if one tells it to you'

Paul testified that nothing except what the prophets and Moses said would come to pass: 'that the Christ must suffer and that by being the first to rise from the dead, he would proclaim light to our people and to the Gentiles' (26:23).

These references to the Scriptures and/or the will of God indicate that the entire biography of Jesus - disputed as it may have been in Israel and leading up to the rejection of Jesus - carries God's stamp of approval. The following point is closely related to this.

\section{Jesus as the agent of God}

Throughout the missionary speeches there is a distinct emphasis on the centrality of God in the biography of Jesus: ${ }^{77}$ According to Acts 2:22, Jesus was 'a man attested to you by God with mighty works and wonders and signs that God did through him in your midst' (2:22). 'The God of Abraham, the God of Isaac and the God of Jacob, the God of our fathers, glorified his servant Jesus ...' (3:13). 'The God of our fathers raised Jesus ... God exalted him at his right hand ...' (5:30). 'God anointed Jesus of Nazareth with the Holy Spirit and with power: he went about doing good and healing all who were oppressed by the devil, for God was with him' (10:37). 'God has brought to Israel a Saviour, Jesus, as he promised' (13:23). 'God raised Jesus from the dead' (13:30); he fulfilled the promises to the fathers by raising Jesus from the dead' (13:33f., 37). In Jesus, God was 'doing a work in your days, a work that you will not believe, even if one tells it to you' (13:41).

In his death, but also in his entire ministry, Jesus of Nazareth was and is God's Christ. Through these references, the

76.This is even emphasised before a Gentile audience, albeit a Gentile audience well acquainted with Judaism (10:1-8).

77.See also Soards (1994:184-187), for divine authority and activity and the close link between theology and Christology. 
biography of Jesus and God are inseparably linked..$^{78}$ On several occasions, links are made between this God (who acts through his agent Jesus) and the God who acted in the past (when he dealt with Israel). He is the God of our fathers (3:13; $5: 30 ; 7: 32 ; 22: 14 ; 24: 14){ }^{79}$

Based on the summaries in Acts 2:22; 3:26; $10: 36-38$ and 13:23, Wolter (2008) concludes as follows:

They all have in common a distinct interpretation of the story of Jesus, which can be recognised clearly: They present God as the acting subject and portray Jesus as the instrument of God's saving activity to Israel. $^{80}$ (p. 31)

Wilckens (1974) indicates that the Christological titles in the missionary speeches of Acts:

\begin{abstract}
... all designate the central function, in which God placed Jesus in the midst of the time, as a fulfilment of all the promises He had given previously. Jesus is the Christ of God, the servant of God,

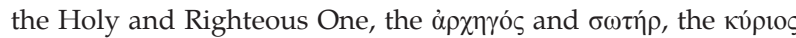
and the Son of God. He is all of this at the same time as the one, through whom God himself acts as his decisive instrument for fulfilling and realising his salvation historical plan and purpose. (p. 178)
\end{abstract}

\section{Israel and the 'Jewishness' of the biography of Jesus and the scope of his ministry}

A further emphasis in the presentation of the biography of Jesus is its distinctly Jewish scope throughout the book of Acts. This aspect of the speeches has received comparatively little attention, despite a number of recent monographs on the role and significance of Israel in Luke-Acts, in particular, the motif of the restoration of Israel. ${ }^{81}$ This Jewish scope appears in three areas.

The Jewishness of Jesus the Saviour: Jesus comes from Nazareth $(2: 22 ; 3: 6 ; 4: 10 ; 6: 14 ; 10: 38 ; 22: 8 ; 26: 9)$. He began his ministry in Galilee after the baptism that the Jewish John proclaimed in the entire region around the Jordan (10:37; Lk 3:3). ${ }^{82}$ Jesus appeared to those who had come up with him from Galilee to Jerusalem (13:31). God has brought to Israel a Saviour, Jesus, from David's descendants (13:22f.). ${ }^{83}$

78.Korn (1993:217) argues that "with the reference to the resurrection in Acts 17, the statements about of God are eventually focused on the Christ-kerygma. This suggests that the Christ-kerygma also had a decisive role in sermons before Gentile audiences'. God is portrayed as the agent to the very end of the speech: He commands all people everywhere to repent, he has fixed a day on which $h$ : will judge the earth ... whom he has appointed ... by raising him from the dead. Therefore, to play on Korn's words, one might add: 'the statements about Jesus also emphasize the proclamation about God'.

79. It would be interesting to examine how Luke-Acts speaks about God in the context of references to Jesus. The speeches in Lystra and in Athens speak about God's being and his role as creator and as the patient, gracious sustainer of the world and its inhabitants.

80.This theocentric focus is also apparent in the references to the 'passion, death and resurrection of Jesus ... Also in these references the fate of the resurrection is always described as God acting on Jesus'.

81.For examples, see Wasserberg (1998), Moessner (1999) and Fuller (2006); see my comments on Fuller and the issue in Stenschke (2008:69-105).

82. Methodological care is required when - at times - far-reaching conclusions are drawn from Jesus' upbringing in Galilee as to his ethnic or religious identity or the nature of his message; for a particularly questionable example in the context of nazi ideology, see Deines (2007:43-131).

83.Jesus' origin is known (a matter of honour and shame in the ancient world; cf Hanson \& Oakman 2008, passim). His humble earthly origins are not denied, but mentioned.
Given these references, it was not necessary to specifically identify Jesus as a Jew (which happens nowhere in the New Testament).

Judaea and Jerusalem as the stage of the biography of Jesus: The ministry of Jesus (and its consequences in the early church) happened throughout all Judaea, beginning from Galilee (10:37). Jesus ministered 'both in the country of the Jews and in Jerusalem' (10:39). ${ }^{84}$ The resurrection appearances of Jesus took place in Jerusalem (13:32). The inhabitants of Jerusalem and their rulers condemned Jesus (13:27). Pontius Pilate was involved in the death of Jesus in his function as praefectus Iduaea (according to the inscription bearing his name discovered in Caesarea ${ }^{85}$ ). This also places the events in Judaea.

The Jews as primary recipients of salvation in references to the biography of Jesus: God sent Jesus first to the Jews (3:26). God gives repentance to Israel and grants her the forgiveness of sins (5:31). 'As for the word that God sent to Israel ...' (10:36). ${ }^{86}$ The disciples were commissioned to preach to the people (of Israel) (10:42). From David's offspring God has brought to Israel a Saviour, Jesus, as he promised (13:23). ${ }^{87}$ Before Jesus' coming, John had proclaimed a baptism of repentance to all the people of Israel (13:24). What God had promised to the fathers, this he has fulfilled to us their children by raising Jesus (13:32f.). Paul had to testify about Jesus in Jerusalem, before he also had to testify in Rome (23:11). 'Jesus would proclaim light both to our people and the Gentiles' (26:23). In this primary focus of the biography of Jesus on Israel, the promises to the fathers were fulfilled $(13: 23,32 \mathrm{f}.){ }^{88}$

Thus, the thoroughly Jewish origin of Jesus, the scope of his ministry in all of Judaea, Galilee and Jerusalem and of the Jews as the primary recipients of Jesus the Saviour appear in the missionary speeches of Acts. After salvation has come to Israel, after Israel has been re-gathered and restored in the ministry of Jesus and in the early Jerusalem community (cf. Zwiep 2004) this salvation may venture forth to the Gentiles.

Through the references to the patriarchs ('the God of Abraham, the God of Isaac, the God of Jacob, the God of our

84.These geographical references need to be seen in view of the recent assessment of the cultural identity and significance of Judaea in the 1st century CE.

85.'... Pontius Pilatus praefectus ludaeae', full text, translation and discussion in Eck (2007:16, 34-43).

86.The deep conviction that God's Christ is obviously for Israel is reflected in Peter's reaction of surprise in Acts 10:34f. (in the only missionary speech in a narrow sense reaction of surprise in Acts 10:34f. (in the only missionary speech in a narrow sense before a predominantly Gentile audience). Whilst Peter proclaims Jesus as Lord of
all $(10: 36)$ and as the judge of (all) the living and the dead, and whilst he speaks of all (10:36) and as the judge of (all) the living and the dead, and whilst he speaks of
forgiveness of sins through his name for everyone who believes in Jesus (10:42f.), forgiveness of sins through his name for everyone who believes in Jesus (10:42f.),
the presentation of the biography of Jesus and its scope has a distinctly Jewish focus.

87.The death of Jesus also occurred in Jerusalem through Jewish instigation (and some involvement of Gentiles, most strongly in $4: 26 f$., which is a prayer of the church, not a missionary speech). Outside of Jerusalem the Jews are not directly or personally charged with the rejection of Jesus or any responsibility for it. Acts 13 suggests that there is no interest in a detailed presentation of who was Acts 13 suggests that there is no interest in a detailed presentation of who was involved in which events. A careful reading of Acts forbids the later notion that all Jews (and of all times) were somehow involved in the 'murder' of Jesus and therefore rejected by God and easy targets for Christian polemics, various form McManus (2005:171f.), Svartvik (2005:343f.) and Bowe (2005:332f.).

88.There are clear similarities to Paul's argumentation in Romans 11. 
fathers, glorified his servant Jesus ...'; 3:13) to Moses (3:22; $13: 39 ; 26: 22)$ and to David $(2: 25,29,34 ; 13: 22,34,36){ }^{89}$ to important and representative figures in the history of Israel, and in the context of references to his biography, Jesus' life is set in the larger context of God's dealing with Israel and in salvation history. Luke thus emphasises that the bios of Jesus is part of the history of Israel. J. Jervell once noted that Luke 'did not write the history of a religious movement or sect, but the final part of the history of the people of the God of Israel'..$^{90}$ To play on his words: Luke did not write the biography of Jesus, but a further chapter on and of the history of the people of Israel. The present as well as the future of Israel and of the nations will be determined by Jesus.

In view of this emphasis on the Jewish scope of the speeches, the universal perspective in Luke-Acts should also be noted: $:^{91}$

- In the quotation from Joel 2:28-32 the universal statements 'I will pour out my Spirit on all flesh ... and it shall come to pass that everyone who calls upon the name of the Lord shall be saved' in Acts 2:17a, 21 frame the statements that apply directly to Israel $(2: 17 \mathrm{~b}-18)$.

- Whilst the Jews of Jerusalem 'are the sons of the prophets and of the covenant that God made with their fathers', Acts 3:25 continues with 'saying to Abraham: "And in your offspring shall all the families of the earth be blessed"'. The following statement, 'God, having raised up his servant, sent him to you first, to bless you by turning everyone of you from your wickedness' (3:26), emphasises the priority of Israel. It further implies that others may also be blessed.

- Jesus the Christ is Lord of all (10:36). Although God allowed in past generations all the nations to walk in their own ways, he did not leave himself without a witness to the nations: 'for he did good by giving you rains from heaven and fruitful seasons, satisfying your hearts with food and gladness' (14:16f.). God gives to all of humanity life and breath and everything (17:25; see also 17:26-31).

- The Lukan genealogy of Jesus moves from Luke 3:34 on backwards beyond Abraham. Ultimately Jesus appears as the son of Adam, the son of God (3:38; in contrast to Mt 1:1f., where Jesus is called the son of David, the son of Abraham; the following genealogy starts with Abraham). Without being named, Adam also appears in Acts 17:26: 'And God made from one [man] every nation of humanity.'

- Whilst some of the titles used for Jesus are distinctly Jewish and only make sense against this background (e.g. Christ or servant), other titles are more general in their scope and also make sense apart from a Jewish background: Jesus is the Saviour $(5: 31 ; 13: 23)$, the 'Son of God' (9:20; cf. Mk 15:39), the 'Holy and Righteous One' (3:14) and the Author or Leader of life (3:15). ${ }^{92}$ Paul 'testified to both Jews and Greeks of repentance toward

89. On David, see Miura (2007).

90.Quoted from Dunn (2009:401); see also Nolland (1998:63-81).

91.According to Soards (1994:204), the universal significance of God's salvation is found in many places and various ways in Acts, but is prominent in 1:8; 2:17-21 39 ; 10:36, 43, 47; 11:17; 13:38b-39, 47; 14:15c; 15:8f.; 17:30; 18:6d; 20:31; 22:14f., 21; 26:12-18, 23, 25f.; 28:28.

92.Cf. J. den Boeft, 'Saviour', DDD, 733-736; J. Fossum, 'Son of God', DDD, 788-794; F. van Koppen, K. van der Torn, 'Holy One', DDD, 415-418; on Lukan Christology see Buckwalter (1998:107-123).
God and of faith in our Lord Jesus Christ' (20:21). These titles guide non-Jewish listeners or readers in their understanding of Jesus.

In addition to this Jewish scope of references to Jesus' biography, Jesus is also placed in a chronology. What God did through Jesus for his people Israel happened not only at particular places and (primarily or initially) for a particular people, but also at a particular time, namely: 'after the baptism that John proclaimed' (10:37) and 'whom you delivered and denied in the presence of Pilate' (3:13); '... they asked Pilate to have him executed' (13:28). The references to Pontius Pilate by name serve to date the events to a specific period of time, namely 26-36 AD. ${ }^{93}$ In Luke's portrayal, the biography of Jesus did not happen in myth or legend but in concrete places and at a determined time (cf. also Lk 1:5; 2:1f.; 3:1f.). ${ }^{94}$

Given that Luke does not present a proper missionary speech before Gentile audiences other than in Acts 10,95 a number of interesting issues cannot be resolved. For example, why do references to the Jewish scope of the biography of Jesus stop in chapter 13 with the missionary speech in the synagogue of Pisidian Antioch? ${ }^{96}$ It is probably not a question of geographic proximity or distance, because such references appear in Caesarea and also in Pisidian Antioch. The speech in Pisidian Antioch is the last missionary speech in the narrow sense of the term. It is therefore not surprising that later speeches do not contain references to the Jewishness of Jesus. This does not mean that the biography of Jesus, including its Jewish focus, loses its importance.

\section{Consequences drawn from the biography of Jesus}

The missionary speeches offer no mere account of the biography of Jesus. In each case, Pichler (1997) draws consequences from this bios and its significance for the audience:

Throughout the death and resurrection of Jesus are emphasised and the implications of these facts are spelt out either with regard to the present (forgiveness of sins: Acts 2:38; 3:19; 5:31; 10:43; 13:38; the gift of the Spirit: Acts 2:38; $5: 32$ ) or to the eschatological future (Acts 3:20f; $4: 12 ; \mathrm{cf} .10: 42$ ) ... The proclamation of salvation requires a decision from the audience: Acts 2:38; $3: 19$ and 5:31 call the audience to repentance, which finds its concrete expression in baptism in the name of Jesus (2:38) and in turning to him (3:19) or as a call to faith in the exalted Christ $(10: 43 ; 13: 38)$. (p. 62) ${ }^{97}$

Paul summarises his proclamation as 'testifying to both Jews and Greeks of repentance toward God and of faith in our Lord Jesus Christ' (20:21).

93. See also Acts 4:27 ('for truly in this city there were gathered together against you holy servant Jesus ... both Herod and Pontius Pilate'). For a detailed discussion, see holy servant Jesus ... both Herod and Pontius Pilate'). For a detailed discussion,
Frey, Krauter and Lichtenberger (2009), in particular Dunn (2009:385-401).

94.This important aspect in the gospel accounts and in Acts was included in the Apostolic Creed: 'crucified under Pontius Pilate'. That is how and why Pilate is mentioned by name in the most prominent creed of Christianity.

95.The speeches in Acts 14 and 17 are in a different category. God is proclaimed as creator, not as the God of Israel (which would be counter-productive for the setting of these speeches; cf. Ac 16:20; 19:33f.). (The election and history of Israel plays no role in the correction of Gentile misunderstandings of the Christian proclamation. God the creator and his appropriate veneration can - to some extent - be understood apart from his election and subsequent dealings with Israel.

96.Cf. Acts 16:22; 19:33f.; 22:8, 14, 17; 23:11. Paul proclaims Christ Jesus to Felix (24:24). The adequate proclamation of Jesus as 'Christ' is impossible without reference to Israel.

97.Pichler (1997:62). See also Acts 13:38-41. 
Acts also reports the human reactions to the proclamation of the gospel in repentance, faith and baptism (e.g. 2:37-41; 4:4; 8:12f.; 10:44-48; 13:8, 43, 48; 17:34) ${ }^{98}$ and in rejection (e.g. 4:2f.; $5: 33 ; 7: 54,57 f . ; 13: 8,45,50 ; 17: 18,32)$. People were not only challenged to respond; in fact, they did respond.

\section{The biography of Jesus and different audiences}

The nature and extent of the presentation of Jesus in the speeches in Acts differs in different locations and before different audiences (see the introduction). In Jerusalem the focus is on the resurrection and exaltation of Jesus; otherwise his public life and death was well known and needed no recounting. On occasions when a basic knowledge of the biography of Jesus cannot be presupposed, it is presented in some detail, so before a Gentile or God-fearing audience in Caesarea (however, even there the basic facts are presupposed as known: 'you yourselves know what happened throughout all Judea', 10:37) ${ }^{99}$ and a Jewish or God-fearing audience in Pisidian Antioch. ${ }^{100}$ What role the biography of Jesus had in missionary endeavours before Gentiles is difficult to assess, particularly given that Acts 13 is the last missionary speech in a narrow sense.

Those who point to Lystra and Athens need to remember that both speeches do not offer the initial proclamation of the apostle(s), but corrections of it, when and where the miracle of healing or the proclamation of Jesus and the resurrection were seriously misunderstood. In Lystra and in Athens, the nature of God and his revelation in creation and history are addressed, not the biography of Jesus. The settings of the speeches allow us to draw only limited conclusions concerning the proclamation.

For D. Flemming (2005:56, and for many others), these speeches are 'compelling examples of evangelistic contextualisation'. His chapter on the 'The preaching of Paul' (2005:56-88) includes a comprehensive chart comparing the speeches in Acts 13:13-52, 14:8-20 and 17:16-34 and an evaluation of the comparison. At least for our understanding of the role of the biography of Jesus in the missionary speeches, however, it makes better sense to compare the more detailed speech of Peter before a Gentile audience with that of Paul in Pisidian Antioch. Acts 14 and 17 are examples of praeparatio evangelica, not evangelistic speeches (in the previous Lukan definition of gospel).

In a comparison between speeches to different audiences, the use of Christological titles is instructive (for the Christological titles, see below). Whilst a plethora of them occur before Jewish audiences, their occurrences before Gentile audiences are limited: Acts 10:36 refers to Jesus Christ, who is Lord of all. Jesus as the Christ is explained later as 'God anointed Jesus of Nazareth with the Holy Spirit and with power' (10:38) in order

98.For the baptismal accounts in Acts, see Avemarie (2002).

99.Korn (1993:219) has argued in detail against the thesis that Acts 10:36-43 is a catechesis for a Christian audience (so Wilckens 1974).

100.It is noteworthy that the circumstances of the death of Jesus are not presented. Audiences outside of Jerusalem are not charged with the rejection of Jesus. to make sense to the audience. Jesus is the judge of the living and the dead (10:42; as such he also appears in 17:31).

Before the Gentile audience in Caesarea the ministry of Jesus is summarised in the terminology of Hellenistic relationships

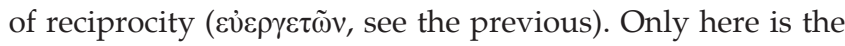
oppression of the devil mentioned and the bodily nature of the resurrection of Jesus emphasised: 'who ate and drank with him after he rose from the dead' (10:41).

Some elements of Peter's proclamation before Cornelius challenge Roman imperial ideology: God shows no partiality (neither to Jews nor to Romans!), all peoples are put on one level before him, God announces the message of peace (pax), Jesus is the Lord of all ( $\pi \alpha \dot{v} \tau \omega v$ kv́pıos). God's decisive and salvific intervention took place in Judaea on the fringes of the empire. ${ }^{101}$

However, one should not overestimate the differences between missionary speeches before Jewish and Gentile audiences, because Acts 10:34-43 is addressed to a Gentile God-fearer, his family and friends and the speech in Pisidian Antioch likewise addresses God-fearers in the audience.

\section{The use of Christological titles}

In the missionary speeches the biography of Jesus is peppered with Christological titles, and biography and titles should not be played off against each other. Jesus as the Christ (and other titles attributed to him) embodies conclusions that were drawn from the biography of Jesus and express his significance. The titles used offer, in fact, an interpretation of the biography of Jesus. ${ }^{102}$ In summaries, the biography of Jesus can hardly be presented apart from such titles: 'A Christology that excludes titular elements cannot reflect the full panorama of the Christological concept' (Pichler 1997:61).

Jesus is repeatedly called the Christ: Acts 2:31, 36; 3:18, 20; 4:10; 5:42 etc. To these occurrences we must add the aforementioned passages in which the early Christian proclamation is mentioned in narrative form (e.g. 5:42: 'they did not cease teaching and preaching Jesus as the Christ'; 'proclaiming to them the Christ'). ${ }^{103}$ Paul proved that Jesus was the Christ (9:22). God preached the good news of peace through Jesus Christ (10:36). Jesus as the Christ implies his Jewish or Davidic roots and other aspects of his life and ministry which, in themselves, provided the evidence for him being the Messiah. The Messiah also implies the kingdom of God (which is closely linked to this figure). Whilst there was no agreement on the details, expectation of one or more Messianic figures was a significant feature of early Jewish

101.On Luke-Acts and Empire, see the survey in Kim (2008:75-190); for an introduction, see Carter (2006).

102.Against Korn (1993:214-225), it needs to be stressed that facts and interpretation in these speeches should not be played off against each other since they are inseparably linked.

103.Philip began proclaiming (Jesus as) the Christ to the Samaritans (Ac 8:5); for detailed treatment see Stenschke (1999:145-147) and Macdonald (1964:362371). According to Acts $8: 12$, the Samaritans believed Philip as he preached the 371). According to Acts 8:12, the Samaritans believed Philip as he preached the
good news about the kingdom of God and the name of Jesus Christ. Again, Christ and the kingdom are closely linked. 
eschatological expectation (see fn. 51). Against the backdrop of this expectation, Jesus was the Messiah in a way that had not been anticipated by many and that therefore needed explanation - along the lines of Jesus' own clarifications in Luke 24. In view of Jesus and his fate, Lukan Christology redefines the concept of Messiah.

In addition to being the Christ, Jesus is called the Lord (2:36),

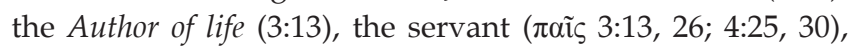
the Holy and Righteous One (3:14; 7:52) and the leader to life $(3: 15 ; 5: 31)$. Jesus is identified as the prophet announced by Moses (3:22). Whether the people listen to this prophet will determine whether they belong to the people of God. As the stone that was rejected by the builders, Jesus has become the cornerstone (4:11). Jesus is the Saviour $(5: 31 ; 13: 23)$. ' He is the Son of God' (9:20). God preached the good news of peace through Jesus Christ, who is Lord of all (10:36) and the judge of the living and the dead (10:42; 17:31). Jesus is proclaimed as the Lord (11:20, 'the teaching of the Lord' in 13:12 probably refers to the Gospel). Paul's summary of his proclamation as 'testifying to both Jews and Greeks of repentance toward God and of faith in our Lord Jesus Christ' (20:21) encapsulates the whole biography of Jesus. Pichler (1997) notes:

This allows for the conclusion that Luke is aware of a plurality of ways of expressing the Christ-event adequately. But perhaps the full range of Christological titles needs to be taken into account, to ensure that all dimensions of the Christ-event are properly presented. The full richness of Christological titles serves a consciously broad reflexion of the significance of the sending and the fate of Jesus with regard to humanity. (p. 61) ${ }^{104}$

A particular feature in the speeches of Acts in the context of some of the Christological titles is what has been called 'exaltation Christology'. It finds expressions in statements like the following: 'This Jesus God raised up ... being therefore exalted at the right hand of God ... God has made him both Lord and Messiah, this Jesus whom you crucified' (2:32, 36; see also 3:20). ${ }^{105}$ In this context reference is made to Psalms 2:7 and 110:1, which play a major role in New Testament Christology. In the critical reconstruction of the development of early Christian Christology, these and similar statements have been understood as an indication of a 'low' Christology or a Christology 'from below'. According to some scholars, this implies that, according to the early Christian understanding of him, Jesus started out as a mere human being and only later on came to be exalted by God to become his Son, the Christ and the Lord. Whilst this feature appears in the speeches of Acts, other references in LukeActs indicate that in the Lukan portrayal, Jesus was far more than a mere human from the very beginning: the infancy narratives indicate that the son named Jesus to be born to Mary will be great and will be called the Son of the Most High,

104.On Jesus as Lord in Acts see Dunn (1998:241-253).

105. Barrett (1998:Ixxxv) notes that Jesus 'is of course the Christ, the Messiah, the Lord's anointed king. Or should we say, he will be the Christ? This question is raised with reference to $3: 20$... It is not likely that the verse refers to an appointment lying still reference to $3: 20 \ldots$ It is not likely that the verse refers to an appointment lying still
in the future; Luke undoubtedly believed that Jesus was the Christ from his birth in the future; Luke undoubtedly believed that Jesus was the Christ from his birth took a different view, but it is improbable. It does however seem likely that Acts 2:36 took a different view, but it is improbable. It does however seem likely that Acts 2:36
meant originally that Jesus became Christ at the time of his resurrection, though Luke must have been able to accommodate the verse to his own view'. and the Lord God will give him the throne of his ancestor David; to his reign there will be no end (1:32f.). The child to be born will be called the Son of God (1:35). Mary is the mother of Elisabeth's 'Lord' (1:43). 'To you is born this day in the city of David a Saviour, who is the Messiah, the Lord' (2:11), et cetera. On several occasion in Luke's Gospel, Jesus is simply addressed of referred to as 'the Lord'. ${ }^{106}$ In view of this and other evidence, the references to the exaltation of Jesus need and should not be seen as indicative of an early 'low' Christology. Rather, they express that the resurrection and exaltation of Jesus was God's public and definite confirmation and approval of all that Jesus had claimed and done previously as God's emissary, however controversial (and worse) it may have appeared to his contemporaries. ${ }^{107}$

\section{The Biography of Jesus in the missionary speeches of Acts: Reflections for the mission of the church}

The early church continues to fascinate contemporary Christians. For some, particularly those whose denominational background is in the various restoration movements of church history, the New Testament descriptions of the early church serve as blue prints for the life and mission for the church in all ages. If only the early church were emulated as closely as possible, many issues would be resolved! Of particular interest are the methods and strategies in which these exemplary Christians spread the gospel. ${ }^{108}$ Given that there are only a few references to evangelism by churches and rank-and-file Christians in the letters of the New Testament, ${ }^{109}$ the obvious place to search for answers is the book of Acts. How did the early Christians speak of Jesus in their evangelism? The book of Acts fails to provide a detailed blueprint. Yet the aforementioned observations have challenging implications for the present witness of the church.

Firstly the significance of Jesus is not reduced to the significance of his death. More telling than the references to all of the biography of Jesus in Acts is the fact that Luke starts his account of early Christianity, its witness and spread, with a detailed account of the life of Jesus, which is far more encompassing and richer than his death. All of his life is of saving significance. There is therefore a need to 'tell the old, old story' again, and to tell a full version of this story. ${ }^{110}$ This is particularly necessary where the basic facts of the life of Jesus cannot be pre-supposed (as was the case in Jerusalem

106.For surveys of Lukan Christology (in which the titles given to Jesus are an important ingredient) see Barrett (1998:Ixxxv-Ixxxvii); Buckwalter (1998:108123); Fitzmyer (1986:192-219); Green (1995:55-68); Jervell (1996:25-34) and Pokorny (1997:110-120).

107.See Hengel (1995a:119-225) (occurrences in Acts are examined on p. 143f.) and Hengel's survey article (1995b:359-389).

108.The classic study of an earlier generation was Green (1970).

109.For recent studies, see Dickson (2003), Keown (2008) and Ware (2005).

110.In the hymn, Tell me the old, old story (cf. cyberhymnal.org/htm/t/e/tellmoos. htm; viewed 22 March 2014) to which I allude, however, the story is not the biography of Jesus, but a pious reflection of the personal benefits of salvation. 
or Judaea!) or have been misunderstood for various reasons (e.g. by a one-sided presentation of Jesus in the media), be it in Western secular societies or in various non-Western societies. Whilst a short argumentative condensation of the Christian message into Four Spiritual Laws or other summaries might have appealed to an earlier generation, in a postmodern age telling the story of Jesus may be more appropriate. Apart from the lack of reference to Israel or Judaea and the full omission of the earthly ministry of Jesus - as if nothing important happened between his birth by the Virgin Mary and his suffering under Pontius Pilate! - the second article of the Apostolic Creed provides a good blueprint.

What Böttrich (2005) notes for Lukan soteriology applies to the whole biography of Jesus:

Lukan soteriology offers - in so far as it encounters the reader in impressive episodes and scenes of a biographical account a wealth of opportunities for identification and allows time and again a connection with the readers' own biographical experiences. (p. 436) $)^{111}$

Secondly, Jesus and his significance need to be understood and presented in view of the Old Testament. Jesus was and is the fulfilment of God's promises to Israel and the world. This continuity places Jesus firmly in the salvation-historical line from the creation to the consummation of God's purposes for the world.

Thirdly, Jesus is to be proclaimed as the supreme agent of the God of the Judaeo-Christian tradition. He cannot and must not be separated from God as revealed in Scripture; nor is there the God of the Bible apart from his revelation in Jesus Christ - which was announced and prepared for in the Old Testament. ${ }^{112}$ Acts 14 and 17 show that the Christian proclamation can hardly be understood apart from this God. None of the figures of the Old Testament (or others) reach the unique position of Jesus as God's ultimate agent (Heb 1:1-4), and no figure after Jesus has a legitimate claim to be God's agent of salvation or announce God's salvation.

Fourthly, the Jewish origin and character of Jesus and this gospel and the priority of Israel must not be ignored in mission and evangelism. Without the Jewish saviour for Israel, there is no Christian gospel. Neither the Aryan Jesus of Nazi theology (where the stripping of his Jewish identity had reached an all time peak), ${ }^{113}$ nor the Jesus of other Western ideologies or secularism, nor the distinctly African, Asian, Latino or 'Whatever-else-Jesus' in all its kaleidoscopic interpretations is the saviour of the world, but the descendant of David, Jesus of Nazareth, sent first by the God of Israel to the Jewish people. ${ }^{114}$ 'Salvation is from the Jews' (Jn 4:22).

111.The potential for such identification is limited, however, as little of the "normal' life of Jesus is known and as he had a unique role to fulfil.

112.A mere Gottgläubigkeit (a vague belief in the divine) is not Christian faith and prone to ideological tainting as its propagation and fate in Nazi Germany has shown; see de.wikipedia.org/wiki/Gottgläubig (viewed 22 March 2014).

113.See Siegele-Wenschkewitz (1994); Osten-Sacken (2002); Heschel (2008) and the more balanced treatment in Arnhold (2010)

114.For surveys of the different interpretations of Jesus, see Kärkkäinen (2003), Eddy and Beilby (2008:84-92), Levison and Pope-Levison (2008:175-186; further bibliography p. 186). In the later article it is surprising that the sections 'Christology 1-3 (Method in Christology, the Growth of Christological Traditions 'Christology 1-3 (Method in Christology, the Growth of Christological Traditions and Twentieth-Century Christc
Jesus 'came from heaven down as a helpless babe and entered our world, his glory veiled' ${ }^{115}$ But even then he had a clear identity: the helpless babe who entered the world by a Jewish peasant woman from Galilee - through Joseph of Davidic descent - and started in a humble manger in Bethlehem, the city of David, was circumcised 8 days later as required by the Covenant ${ }^{116}$ and given the Jewish name Jesus (Lk 2:21), which embodies Jewish aspirations for God's salvation of his people (Mt 1:21). Shortly thereafter Jesus was brought to the temple in Jerusalem and presented ('as it is written in the Law of the Lord ...'; 2:22f.). Yes, he will be a light for revelation to the Gentiles, which is inseparable from the glory prepared for God's people Israel (2:32). As such, Jesus came to and stayed in Egypt or Africa before he returned to Nazareth and to the temple in Jerusalem (Lk 2:39-51).

In view of this, Jesus himself does not need to be and cannot be 'incarnated' in African, American, Asian, Australian or European soil as has sometimes been demanded. ${ }^{117} \mathrm{He}$ is not the helpless babe whom the peoples of the earth can adopt and make into one of their own. They cannot play with him according to their own liking. He was incarnated into Jewish soil, born in Bethlehem (Lk 2:4-7) as God's son. He was 'born of a woman, born under the Law' (Gl 4:4). As such and only with and because of his identity as God's saviour for Israel, he is and can be the universal saviour and Lord of all, which is why the peoples of the earth can and must adopt him. The Jewish identity of Jesus and the Jewish context of his mission is not merely the cultural form in which the biblical message is clothed and which is not part of the essential message to be reproduced in every culture. ${ }^{118}$

However, because of the universal Lordship of Jesus and the universal offer of salvation, the good news can be and should be incarnated in the different soils of this world ${ }^{119}$ so that people hear and understand what has happened in Judea, beginning in Galilee' (Ac 10:36-43) and appreciate how it applies to them: 'everyone who believes in him receives forgiveness of sins through his name' (10:43): 'The eternal truths we communicate must take flesh in human languages and cultures' (Mondithoka 2007:180). ${ }^{120}$

115.To play on the words of G. Kendrick's worship song of 1983, 'The Servant King' ('From heav'n you came, helpless babe, entered our world, your glory veiled').

116.Cf. Hall (1993:1025-1031).

117.See the survey in Goergen (2001:5-51); see also Neely (2000:474f.) and Mondithoka (2007:177-181).

118.To play on a statement of Musasiwa (2007:69).

119. Often the incarnation of Jesus has been understood as a model for Christian mission; for a survey see Mondithoka (2007:178f.). He further notes: 'Incarnation
has important implications for "critical contextualisation", which means applying has important implications for "critical contextualisation", which means applying
God's truth in a culturally relevant and sensitive manner and yet without compromising its meaning. Here again the incarnation is our model' (Mondithoka 2007:180).

120. For example, there are notable attempts to express the identity of Jesus and of his mission in Asian contexts. Mondithoka describes how Jesus has been interpreted as an avatar, a bodily manifestation of a higher being: 'Christians in India can use the term avatar, familiar to the vast majority of Indians, as a way of introducing Christ' (Mondithoka 2007:180). Raj (2007:183) states that it is possible to identify many hundreds of names (attributes) for Christ in a wide variety of tonguages many hundreds of names (attributes) for Christ in a wide variety of language and cultures and notes: "So to a Hindu convert "guru" does not just mean teacher (equivalent to a rabbi for a Jew); his guru is the one who leads him from ignorance into knowledge, from darkness into light, and so on.' The purpose of these interpretations is 'to enable the gospel message to be readily understood accepted and lived out in the thought-forms of the culture as it is expressed in its vocabulary, art forms and imagery' (Raj 2007:181). He also notes: 'In so far as the gospel "finds a home" in the culture such that it is experiences and understood 
Therefore contextualisation and acculturation of the Gospel (and the community created by faith in it) is necessary and legitimate. ${ }^{121}$ First attempts at doing so can be observed in the book of Acts itself and elsewhere in the New Testament (see Flemming 2005:56-88).

All of Jesus' life up to the ascension ${ }^{122}$ and his future return to Zion (cf. Rm 11:26) happened in all of Judaea, an area between the continents which were known in ancient times and which had become the promised land for Abraham and his descendants centuries before. Africa, Asia and Europe, therefore, so to speak, had Jesus in their midst, to hold and to cherish, but not to make him fully their own. If he is made fully one of them, he ceases to be God's Christ for Israel and the nations.

Fifthly, the proclamation of Jesus is inadequate if it does not lead to a challenge on the part of the audience to respond in repentance, faith and baptism, expressing commitment to the risen and exalted Jesus. Only then has evangelism reached its goal. To inform people about Jesus is but a first step.

Sixthly, the manner of the presentation of Jesus and his resurrection is determined by the amount of knowledge that can be presupposed for the audience. The references in Acts provide the content of the gospel, but provide no detailed guidance on how it is to be communicated when and where Jewish background is fully lacking. The resurrection of Jesus is central. For the resurrection to make sense, the events prior to this supreme act of divine approval and the present life of Jesus need to be included. It is clear that an exclusive focus on the death of Jesus, in whatever depth it may be presented, is not sufficient. The thoroughly (and often only) human Jesus, the wisdom teacher from Galilee needs to be supplemented by the risen and exalted Lord, the Christus victor, and the returning universal judge in the witness of the church (see Eddy \& Beilby 2008:85-87).

Lastly, the story of Jesus and Christological titles goes hand in hand, as the titles embody the story. In order for these titles to have their full impact, they will have to be explained in catechesis and in evangelism. A mere firework of Christological titles (and soteriological technical terminology) is not a meaningful communication of the Gospel.

(Footnote 120 continues...) through particular and recognisable cultural clothing with which its people readily identify, the incarnational principle is at work' Whilst there is the danger of syncretism, there is also the promise of the enrichment of there is the danger of the gospel, since inculturation 'brings to light aspects of its truth which may have remained hidden in other cultural contexts' (Raj 2007:183). Later on, Raj speaks of a reincarnation of the Gospel: 'for unless the good news of Christ is reincarnated in every cultural context it will not be seen and experienced as good news' (Raj 2007:183).

121.For brief surveys of the issues, see Martínez (2008:1f.); Gener (2008:192-196); Schreiter (2008:500-502); Gener, Bautista and Vanhoozer (2008:889-898); Gilliland (2000:225-227); Musasiwa (2007:66-71, with a focus on Africa) and Bevans (2002).

122.It is noteworthy that the ascension of Jesus took place on the mount called Olivet, which is a 'Sabbath day's journey away' from Jerusalem, in the immediate vicinity (Ac 1:12). This is where Jesus had led the apostles - within the limits that pious Jews were allowed to walk on a Sabbath day (according to 1:3, Jesus appeared measurement of the distance in terms of what was permitted on the Sabbath measurement of the distance in terms of what was permitted on the Sabbath
might suggest that the Ascension took place on a Sabbath. ... The detail does might suggest that the Ascension took place on a Sabbath. ... The detail does
$\ldots$ add to the Jewish atmosphere of the opening chapters of Acts.' From his circumcision to his ascension, Jesus the Jew is firmly placed in Judaism. Despite some controversies with the Jewish leaders of his time, Jewish piety played an important role in his life.
Christian witness in the wake of the apostles is first and foremost witness to Jesus as God's agent of salvation and in particular to his resurrection. This God-centeredness and Christ-centeredness is the standard against which all witnesses and evangelism in word and deeds need to be measured in order to be truly apostolic.

\section{Conclusion}

The book of Acts offers a fascinating portrayal and interpretation of Jesus. His life is not reduced to his atoning death and/or resurrection, but described in some detail (past, present and future) and with several emphases, for example, all of this life is salvific for Jews and Gentiles alike. Particularly noteworthy is the emphasis on the 'Jewishness' of Jesus and his ministry. This comprehensive portrayal should be compared to other New Testament Christologies and soteriologies. In addition, this comprehensive portrayal has several implications for the mission of the church and its task of contextualising Jesus.

\section{Acknowledgements Competing interests}

The author declares that he has no financial or personal relationship(s) that may have inappropriately influenced him in writing this article.

\section{References}

Anderson, K.L., 2006, 'But God Raised Him from the Dead': The Theology of Jesus' Resurrection in Luke-Acts, Paternoster Biblical Monographs, Paternoster, Bletchley, Milton Keynes.

Arnhold, O., 2010, 'Entjudung' - Kirche im Abgrund: Die Thüringer Kirchenbewegung Deutsche Christen 1928-1939 und das 'Institut zur Erforschung und Beseitigung des jüdischen Einflusses auf das deutsche kirchliche Leben' 1939-1945, Institut Kirche und Judentum, Zentrum für Christlich-Jüdische Studien an der HumboldtUniversität zu Berlin, Berlin. (Studien zu Kirche und Israel 25, 1\&2).

Avemarie, F. \& Lichtenberger, H. (eds.), 2001, Auferstehung - Resurrection: The Fourth Durham-Tübingen Research Symposium: Resurrection, Transformation, and Exaltation in the Old Testament, Ancient Judaism, and Early Christianity, Mohr Siebeck, Tübingen. (WUNT 135).

Avemarie, F., 2002, Die Tauferzählungen der Apostelgeschichte: Theologie und Geschichte, Mohr Siebeck, Tübingen. (WUNT 139).

Aviam, M., 2007, 'Distribution Maps of Archaeological Data From the Galilee: An Attempt to Establish Zones Indicative of Ethnicity and Religious Affiliation', in J. Zangenberg, H. Attridge \& D.B. Martin (eds.), Religion, Ethnicity and Identity in Ancient Galilee, pp. 115-132, Mohr Siebeck, Tübingen. (WUNT 210).

Barrett, C.K., 1994, A Critical and Exegetical Commentary on the Acts of the Apostles I: Preliminary Introduction and Commentary on Acts I-XIV, ICC, T. \& T. Clark, Edinburgh.

Barrett, C.K., 1998, A Critical and Exegetical Commentary on the Acts of the Apostles II: Introduction and Commentary on Acts XV-XXVIII, ICC, T. \& T. Clark, Edinburgh.

Bauckham, R., 1996, 'Kerygmatic Summaries in the Speeches of Acts', in B. Witherington (ed.), History, Literature and Society in the Book of Acts, pp. 185-217, Cambridge University Press, Cambridge. http://dx.doi.org/10.1017/ 185-217, Cambridge Unive
CB09780511555176.009

Bayer, H.F., 1998, 'The Preaching of Peter in Acts', in I.H. Marshall \& D. Peterson (eds.) Witness to the Gospel: The Theology of Acts, pp. 257-274, Eerdmans, Grand Rapids, Cambridge, UK.

Bevans, S.B., 2002, Models of Contextual Theology, Orbis, Maryknoll.

Bock, D.L., 1987, Proclamation from Prophecy and Pattern: Lucan Old Testament Christology, JSOT, Sheffield. (JSNT.S 12).

Bock, D.L., 1998, 'Scripture and the Realisation of God's promises', in I.H. Marshal \& D. Peterson (eds.), Witness to the Gospel: The Theology of Acts, pp. 19-39, Eerdmans, Grand Rapids, Cambridge, UK.

Böttrich, C., 2005, 'Proexistenz im Leben und Sterben: Jesu Tod bei Lukas', in J. Frey $\&$ J. Schröter (eds.), Deutungen des Todes Jesu, pp. 413-436, Mohr Siebeck, Tübingen. (WUNT 181)

Bovon, F., 2006, Luke the Theologian: Fifty Five Years of Research (1950-2005), Baylor University Press, Waco. 
Bowe, B.R., 2005, 'Passion Narratives', in E. Kessler \& N. Wenborn (eds.), A Dictionary of Jewish-Christian Relations, p. 332f., Cambridge University Press, Cambridge.

Buckwalter, H.D., 1998, 'The Divine Saviour', in I.H. Marshall \& D. Peterson (eds.) Witness to the Gospel: The Theology of Acts, pp. 107-123, Eerdmans, Grand Rapids, Cambridge, UK

Busse, U., 2011, 'Eschatologie in der Apostelgeschichte', in J. van der Watt (ed.), Eschatology of the New Testament and Some Related Documents, pp. 141-178, Mohr Siebeck, Tübingen. (WUNT II 315).

Carter, W., 2006, The Roman Empire and the New Testament: An Essential Guide, Abingdon, Nashville.

Chancey, M.A., 2002, The Myth of a Gentile Galilee, Cambridge University Press, Cambridge. (SNTS.MS 118). http://dx.doi.org/10.1017/CBO9780511487927

Chester, A., 2006, Messiah and Exaltation: Jewish Messianic and Visionary Traditions and New Testament Christology, Mohr Siebeck, Tübingen. (WUNT 207).

Conzelmann, H., 1964, Die Mitte der Zeit: Studien zur Theologie des Lukas, 5th edn., Mohr Siebeck, Tübingen. (BHTh 17).

Crossan, J.D., 1991, The Historical Jesus: The Life of a Mediterranean Jewish Peasant T. \& T. Clark, Edinburgh.

Deines, R., 2007, 'Jesus der Galiläer: Traditionsgeschichte und Genese eines antisemitischen Konstrukts bei Walter Grundmann', in R. Deines, V. Leppin \& K. W. Niebuhr (eds.), Walter Grundmann: Ein Neutestamentler im Dritten Reich, pp. 43-131, Evangelische Verlagsanstalt, Leipzig. (AKThG 21).

Delling, G., 1972/1973, 'Die Jesusgeschichte in der Verkündigung nach Acta', New Testament Studies 19, 373-389.

Dettwiler, A. \& Zumstein, J. (eds.), 2002, Kreuzestheologie im Neuen Testament, Mohr Siebeck, Tübingen. (WUNT 151).

Dickson, J.P., 2003, Mission-Commitment in Ancient Judaism and in the Pauline Communities: The Shape, Extent and Background of Early Christian Mission, Mohr Communities: The Shape, Extent and
Siebeck, Tübingen. (WUNT II.159).

Dunn, J.D.G., 1998, 'KYRIOS in Acts', in J.D.G. Dunn (ed.), The Christ and The Spirit I: Christology, pp. 241-253, Eerdmans, Grand Rapids, Cambridge, UK.

Dunn, J.D.G., 2009, 'The Book of Acts as Salvation History', in J. Frey, S. Krauter \& H. Lichtenberger (eds.), Heil und Geschichte: Die Geschichtsbezogenheit des Heils und das Problem der Heilsgeschichte in der biblischen Tradition und in der theologischen Deutung, pp. 385-401, Mohr Siebeck, Tübingen. (WUNT 248).

Eck, W., 2007, Rom und Judaea: Fünf Vorträge zur römischen Herrschaft in Palaestina, Mohr Siebeck, Tübingen. (Tria Corda 2).

Eddy, P.R. \& Beilby, J., 2008, 'Atonement', in W.A. Dyrness \& V.-M. Kärkkäinen (eds.) Global Dictionary of Theology: A Resource for the Worldwide Church, pp. 84-92, InterVarsity Press Academic, Grand Rapids, Cambridge, UK; InterVarsity Press, Nottingham.

Eskola, T., 2001, Messiah and the Throne: Merkabah Mysticism and Early Christian Exaltation Discourse, Mohr Siebeck, Tübingen. (WUNT II.142).

Fisher, E.J. \& McManus, D.D., 2005, 'Good Friday Prayer for the Perfidious Jews', in E. Kessler \& N. Wenborn (eds.), A Dictionary of Jewish-Christian Relations, p. $171 \mathrm{f}$. Cambridge University Press, Cambridge.

Fitzmyer, J.A., 1986, The Gospel According to Luke I-IX, 2nd edn., Doubleday, Garden City. (Anc B 28).

Flemming, D., 2005, Contextualization in the New Testament: Patterns for Theology and Mission, InterVarsity Press, Downers Grove.

Frey, J., Rothschild, C.K. \& Schröter, J. (eds.), 2009, Die Apostelgeschichte im Kontext antiker und frühchristlicher Historiographie, de Gruyter, Berlin, New York. (BZNW 162)

Frey, J., Krauter, S. \& Lichtenberger, H. (eds.), 2009, Heil und Geschichte: Die Geschichtsbezogenheit des Heils und das Problem der Heilsgeschichte in der biblischen Tradition und in der theologischen Deutung, Mohr Siebeck, Tübingen. (WUNT 248).

Fuller, M.E., 2006, The Restoration of Israel: Israel's Re-gathering and the Fate of the Nations in Early Jewish Literature and Luke-Acts, de Gruyter, Berlin, New York. (BZNW 138).

Garrett, S.R., 1989, The Demise of the Devil: Magic and the Demonic in Luke-Acts, Fortress, Minneapolis.

Gempf, C.H., 1988, 'Historical and Literary Appropriateness in the Mission Speeches in Acts', PhD thesis, Dept. of New Testament, University of Aberdeen.

Gempf, C.H., 1993, 'Public Speaking and Published Accounts', in B.W. Winter \& A.D. Clarke (eds.), The Book of Acts in Its Ancient Literary Setting, pp. 259-303, Eerdmans, Grand Rapids, Cambridge, UK; Paternoster, Carlisle. (AFCS I).

Gener, T.D., 2008, 'Contextualisation', in W.A. Dyrness \& V.-M. Kärkkäinen (eds.), Global Dictionary of Theology: A Resource for the Worldwide Church, pp. 192196, InterVarsity Press Academic, Grand Rapids, Cambridge, UK; InterVarsity Press, Nottingham.

Gener, T.D., Bautista, L. \& Vanhoozer, K.J., 2008, 'Theological Method', in W.A. Dyrness \& V.-M. Kärkkäinen (eds.), Global Dictionary of Theology: A Resource for the Worldwide Church, pp. 889-898, InterVarsity Press Academic, Grand Rapids, Cambridge, UK; InterVarsity Press, Nottingham.

Gewieß, J., 1939, Die urapostolische Heilsverkündigung nach der Apostelgeschichte, Müller \& Seifert, Breslau. (BSHT NF 5).

Gilliland, D., 2000, 'Contextualization', in A.S. Moreau (ed.), Evangelical Dictionary of World Missions, pp. 225-227, Baker, Grand Rapids.

Goergen, D.J., 2001, 'The Quest for the Christ of Africa', African Christian Studies 17, 5-51.
Glöckner, R., 1976, Die Verkündigung des Heils beim Evangelisten Lukas, Grünewald, Mainz. (WSAMA.T 9).

Green, M., 1970, Evangelism in the Early Church, Hodder \& Stoughton, London.

Green, J.B., 1995, The Theology of the Gospel of Luke, New Testament Theology, Cambridge University Press, Cambridge. http://dx.doi.org/10.1017/ CBO9781139166683

Green, J.B., 1996, 'Internal Repetition in Luke-Acts: Contemporary Narratology and Lukan Historiography', in B. Witherington (ed.). History, Literature and Society in the Book of Acts, pp. 283-299, Cambridge University Press, Cambridge. http:// dx.doi.org/10.1017/СBO9780511555176.012

Hall, R.G., 1993, 'Circumcision', AncBD I, 1025-1031.

Hansen, G.W., 1998, 'The Preaching and Defence of Paul', in I.H. Marshall \& D. Peterson (eds.), Witness to the Gospel: The Theology of Acts, pp. 295-324, Eerdmans, Grand Rapids, Cambridge, UK.

Hanson, K.C. \& Oakman, D.E., 2008, Palestine in the Time of Jesus: Social Structures and Social Conflicts, 2nd edn., Fortress, Minneapolis.

Hengel, M., 1995a, "'Sit at My Right Hand!": The Enthronement of Christ at the Right Hand of God and Psalm 110:1', in M. Hengel (ed.), Studies in Early Christology, pp. 119-225, T. \& T. Clark, Edinburgh.

Hengel, M., 1995b, 'Christological Titles in Early Christianity', in M. Hengel (ed.), Studies in Early Christology, pp. 359-389, T. \& T. Clark, Edinburgh.

Hengel, M., 2003, 'Jesus der Messias Israels', in M. Hengel \& A.M. Schwemer (eds.), Der messianische Anspruch Jesu und die Anfänge der Christologie: Vier Studien, pp. 1-80, Mohr Siebeck, Tübingen. (WUNT 138).

Hengel, M. \& Schwemer, A.M., 2007, Jesus und das Judentum, Mohr Siebeck, Tübingen. (Geschichte des frühen Christentums I).

Heschel, S., 2008, The Aryan Jesus: Christian Theologians and the Bible in Nazi Germany, Princeton University Press, Princeton, Oxford.

Jervell, J., 1996, The Theology of the Acts of the Apostles, New Testament Theology, Cambridge University Press, Cambridge. http://dx.doi.org/10.1017/ CBO9780511621345

Jervell, J., 1998, Die Apostelgeschichte, Vandenhoeck \& Ruprecht, Göttingen. (KEK 3).

Kärkkäinen, V.-M., 2003, Christology: A Global Introduction, Baker Academic, Grand Rapids.

Käsemann, E., 1964, 'Das Problem des historischen Jesus', in E. Käsemann (ed.), Exegetische Versuche und Besinnungen, pp. 105-131, Evangelische Verlagsanstalt, Berlin.

Karrer, M., 1990, Der Gesalbte: Die Grundlagen des Christustitels, Vandenhoeck \& Ruprecht, Göttingen. (FRLANT 151).

Keown, M.J., 2008, Congregational Evangelism in Philippians: The Centrality of an Appeal for Gospel Proclamation to the Fabric of Philippians, Paternoster Biblical Monographs, Paternoster, Carlisle.

Kim, S., 2008, Christ and Caesar: The Gospel and the Roman Empire in the Writings of Luke and Paul, Eerdmans, Grand Rapids, Cambridge, UK.

Klein, C. (ed.), 2009, Handbuch Biographie: Methoden, Traditionen, Theorien, J.B. Metzler, Stuttgart, Weimar.

Kliesch, K., 1975, Das heilsgeschichtliche Credo in den Reden der Apostelgeschichte, Hanstein, Köln, Bonn. (BBB 44).

Korn, M., 1993, Die Geschichte Jesu in veränderter Zeit: Studien zur bleibenden Bedeutung Jesu im lukanischen Doppelwerk, Mohr Siebeck, Tübingen. (WUNT II 51).

Lee, A.H.I. 2005, From Messiah to Preexistent Son: Jesus' Self-Consciousness and Early Christian Exegesis of Messianic Psalms, Mohr Siebeck, Tübingen. (WUNT II 192).

Levison, J. \& Pope-Levison, P., 2008, 'Christology 4. The New Contextual Theologies: Liberation and Inculturation', in W.A. Dyrness \& V.-M. Kärkkäinen (eds.), Global Dictionary of Theology: A Resource for the Worldwide Church, pp. 175-186, InterVarsity Press Academic, Grand Rapids, Cambridge, UK. InterVarsity Press, Nottingham.

Macdonald, J., 1964, The Theology of the Samaritans, New Testament Library, SCM, London.

Marshall, I.H., 1993, 'Acts and the "Former Treatise"', in B.W. Winter \& A.D. Clarke (eds.), The Book of Acts in Its Ancient Literary Setting, pp. 163-182, Eerdmans, Grand Rapids, Cambridge, UK; Paternoster, Carlisle. (AFCS I).

Marshall, I.H., 1992, The Acts of the Apostles, New Testament Guides, JSOT, Sheffield.

Marshall, J., 2009, Jesus, Patrons and Benefactors: Roman Palestine and the Gospel of Luke, Mohr Siebeck, Tübingen. (WUNT II 259).

Martínez, J.F., 2008, 'Acculturation', in W.A. Dyrness \& V.-M. Kärkkäinen (eds.), Globa Dictionary of Theology: A Resource for the Worldwide Church, p. 1f., InterVarsity Press Academic, Grand Rapids, Cambridge, UK; InterVarsity Press, Nottingham.

Mittmann-Richert, U., 2008, Der Sühnetod des Gottesknechts: Jesaja 53 im Lukasevangelium, Mohr Siebeck, Tübingen. (WUNT 220).

Miura, Y., 2007, David in Luke-Acts: His Portrayal in the Light of Early Judaism, Mohr Siebeck, Tübingen. (WUNT II 232).

Moessner, D.P. (ed.), 1999, Jesus and the Heritage of Israel: Luke's Narrative Claim upon Israel's Legacy, Trinity Press International, Harrisburg. (Luke the Interpreter of Israel 1).

Mondithoka, S., 2007, 'Incarnation', in J. Corrie (ed.), Dictionary of Mission Theology Evangelical Foundations, pp. 177-181, InterVarsity Press, Nottingham, Downers Grove. (IVP Reference Collection).

Musasiwa, R., 2007, 'Contextualization', in J. Corrie (ed.), Dictionary of Mission Theology: Evangelical Foundations, pp. 66-71, InterVarsity Press, Nottingham, Downers Grove. (IVP Reference Collection). 
Neely, A., 2000, 'Incarnational Mission', in A.S. Moreau (ed.), Evangelical Dictionary of World Missions, p. 474f., Baker, Grand Rapids.

Nolland, J., 1998, 'Salvation-history and Eschatology', in I.H. Marshall \& D. Peterson (eds.), Witness to the Gospel: The Theology of Acts, pp. 63-81, Eerdmans, Grand Rapids, Cambridge, UK

Oegema, G.S., 1994, Der Gesalbte und sein Volk: Untersuchungen zum Konzeptualisierungsprozess der messianischen Erwartungen von den Makkabäern bis Bar Kochba, Vandenhoeck \& Ruprecht, Göttingen. (Schriften des Institutum Judaicum Delitzschianum 2).

Oegema, G.S., 2008, 'Messianism and Messianic Figures in Second Temple Judaism' in C.A. Evans (ed.), Encyclopedia of the Historical Jesus, pp. 406-409, Routledge, London, New York.

Ostmeyer, K.-H., 2005, 'Armenhaus und Räuberhöhle? Galiläa zur Zeit Jesu', Zeitschrift für die neutestamentliche Wissenschaft 96, 147-170.

Palmer, D.W., 1993, 'Acts and the Ancient Historical Monograph', in B.W. Winter \& A.D. Clarke (eds.), The Book of Acts in Its Ancient Literary Setting, pp. 1-29, Paternoster, Carlisle; Eerdmans, Grand Rapids, Cambridge, UK. (AFCS I).

Pawlikowski, J.T., 2005, 'Christ and Christology', in E. Kessler \& N. Wenborn (eds.), A Dictionary of Jewish-Christian Relations, pp. 85-89, Cambridge University Press, Cambridge.

Pazdan, M.M., 1993, 'Mary, Mother of Jesus', AncBD IV, 584-586.

Pervo, R.I., 2009, Acts: A Commentary, Hermeneia, Fortress, Minneapolis.

Pichler, J., 1997, Paulusrezeption in der Apostelgeschichte: Untersuchungen zur Rede im pisidischen Antiochien, Tyrolia, Innsbruck, Wien. (Innsbrucker theologische Studien 50)

Pokorny, P., 1997, Theologie der lukanischen Schriften, Vandenhoeck \& Ruprecht Göttingen. (FRLANT 174)

Porter, S.E. (ed.), 2007, The Messiah in the Old and New Testaments, McMaster New Testament Studies, Eerdmans, Grand Rapids, Cambridge, UK.

Radl, W., 1975, Paulus und Jesus im lukanischen Doppelwerk: Untersuchungen zu Parallelmotiven im Lukasevangelium und in der Apostelgeschichte, Lang, Bern. (EHS 23 Theologie 49).

Radl, W., 2001, 'Jungfrauengeburt II. Biblisch', RGG IV, $706 f$.

Räisänen, H., 1992, 'Maria/Marienfrömmigkeit I. Neues Testament', TRE 22, 115-119.

Raj, P.S., 2007, 'Inculturation', in J. Corrie (ed.), Dictionary of Mission Theology: Evangelical Foundations, pp. 181-184, InterVarsity Press, Nottingham, Downers Grove. (IVP Reference Collection).

Reed, J.L., 2000, Archaeology and the Galilean Jesus: A Re-Examination of the Evidence, Trinity Press International, Harrisburg.

Rusam, D., 2003, Das Alte Testament bei Lukas, de Gruyter, Berlin, New York. (BZNW 122).

Sanders, J.T., 1987, The Jews in Luke-Acts, SCM, London.

Schaefer, C., 2012, Die Zukunft Israels bei Lukas: Biblisch-frühjüdische Zukunftsvorstellungen im lukanischen Doppelwerk im Vergleich mit Römer 9-11, de Gruyter, Berlin, New York. (BZNW 190).

Schweizer, E., 1957, 'Zu den Reden der Apostelgeschichte', Theologische Zeitschrift 13, 1-11.

Schnabel, E.J., 2004a, Early Christian Mission I: Jesus and the Twelve, InterVarsity Press, Downers Grove.

Schnabel, E.J., 2004b, Early Christian Mission II: Paul and the Early Church, InterVarsity Press, Downers Grove.

Schnelle, U., 2007, Einleitung in das Neue Testament, 6th edn., Vandenhoeck \& Ruprecht, Göttingen. (UTB für Wissenschaft: Theologie 1830).

Schreiter, R., 2008, 'Local Theologies', in W.A. Dyrness \& V.-M. Kärkkäinen (eds.) Global Dictionary of Theology: A Resource for the Worldwide Church, pp. 500502, InterVarsity Press Academic, Grand Rapids, Cambridge, UK; InterVarsity Press, Nottingham.

Schröter, J., 2009, 'Jesus of Galilee: The Role of Location in Understanding Jesus', in J.A Charlesworth \& P. Pokorný (eds.), Jesus Research: An International Perspective The First Princeton - Prague Symposium on Jesus Research, pp. 36-55, Eerdmans, The First Princeton - Prague Sym
Grand Rapids, Cambridge UK.

Schweizer, E., 1989, Jesus Christ: the Man from Nazareth and the Exalted Lord, SCM, London.

Sellner, H.J., 2007, Das Heil Gottes: Studien zur Soteriologie des lukanischen Doppelwerkes, de Gruyter, Berlin, New York. (BZNW 152).
Siegele-Wenschkewitz, L. (ed.), 1994, Christlicher Antijudaismus und Antisemitismus: Theologische und kirchliche Programme Deutscher Christen, Haag \& Herchen, Frankfurt am Main. (Arnoldshainer Texte 85).

Soards, M.L., 1994, The Speeches of Acts: Their Content, Context and Concerns, Westminster John Knox, Louisville.

Squires, J.T., 1993, The Plan of God in Luke-Acts, Cambridge University Press, Cambridge. (SNTS.MS 76). http://dx.doi.org/10.1017/CBO9780511470486

Steck, O.H., 1967, Israel und das gewaltsame Geschick der Propheten: Untersuchungen zur Überlieferung des deuteronomistischen Geschichtsbildes im Alten Testament Spätjudentum und Urchristentum, Neukirchener, Neukirchen-Vluyn. (WMANT 23).

Stenschke, C., 1996, 'Die Bedeutung der Propheten und des Prophetenwortes der Vergangenheit für das lukanische Menschenbild', Jahrbuch für evangelikale Theologie 10, 123-148.

Stenschke, C., 1999, Luke's Portrait of Gentiles Prior to Their Coming to Faith, Mohr Siebeck, Tübingen. (WUNT II 108).

Stenschke, C., 2008, 'Neue Monographien zum lukanischen Doppelwerk: Ein Forschungsbericht', Jahrbuch für evangelikale Theologie 22, 69-105.

Stuhlmacher, P., 2005, Biblische Theologie des Neuen Testaments I: Grundlegung, Von Jesus zu Paulus, 3rd edn., Vandenhoeck \& Ruprecht, Göttingen.

Svartvik, J., 2005, 'Pilate, Pontius', in E. Kessler \& N. Wenborn (eds.), A Dictionary of Jewish-Christian Relations, p. 343f., Cambridge University Press, Cambridge.

Taeger, J.W., 1980, 'Paulus und Lukas über den Menschen', Zeitschrift für die neutestamentliche Wissenschaft 71, 96-108.

Taeger, J.W., 1982, Der Mensch und sein Heil: Studien zum Bild des Menschen und zur Sicht der Bekehrung bei Lukas, G. Mohn, Gütersloh. (Studien zum Neuen Testament 14).

Talbert, C.H., 1992, 'The Place of the Resurrection in the Theology of Luke', Interpretation 44, 19-30. http://dx.doi.org/10.1177/002096439204600103

Tan, K.S., 2007, 'Christ/Christology', in J. Corrie (ed.), Dictionary of Mission Theology: Evangelical Foundations, pp. 47-51, InterVarsity Press, Nottingham, Downers Grove. (IVP Reference Collection).

Van Zyl, H.C., 2002, 'The Soteriological Meaning of Jesus' Death in Luke-Acts: A Survey of Possibilities', Verbum et Ecclesia 23, 533-557. http://dx.doi.org/10.4102/ ve.v23i2.1223

Versnel, H.S., 2005, 'Making Sense of Jesus' Death: The Pagan Contribution', in J. Frey \& J. Schröter (eds.), Deutungen des Todes Jesu, pp. 215-294, Mohr Siebeck, Tübingen. (WUNT 181)

Von der Osten-Sacken, P. (ed.), 2002, Das missbrauchte Evangelium: Studien zu Theologie und Praxis der Thüringer Deutschen Christen, Institut Kirche und Judentum, Berlin.

Von Padberg, L., 2003, Die Inszenierung religiöser Konfrontationen: Theorie und Praxis der Missionspredigt im frühen Mittelalter, Hiersemann Stuttgart. (Monographien zur Geschichte des Mittelalters 51).

Ware, J.P., 2005, The Mission of the Church in Paul's Letter to the Philippians in the Context of Ancient Judaism, Brill, Leiden, Boston. (NT.S 120).

Wasserberg, G., 1998, Aus Israels Mitte - Heil für die Welt: Eine narrativ-exegetische Studie zur Theologie des Lukas, de Gruyter, Berlin, New York. (BZNW 92).

Weatherly, J.A., 1994, Jewish Responsibility for the Death of Jesus in Luke-Acts, Sheffield Academic Press. (JSNT.S 106).

Wilckens, U., 1974, Die Missionsreden der Apostelgeschichte: Form- und traditionsgeschichtliche Untersuchungen, 3rd edn., Neukirchener, NeukirchenVluyn. (WMANT 5)

Winter, B.W., 1996, 'On Introducing Gods to Athens: An Alternative Reading of Acts 17:18-20', Tyndale Bulletin 47, 71-90.

Wolter, M., 2005, 'Der Heilstod Jesu als theologisches Argument', in J. Frey \& J. Schröter (eds.), Deutungen des Todes Jesu, pp. 297-313, Mohr Siebeck, Tübingen. (WUNT 181).

Wolter, M., 2008, Das Lukasevangelium, Mohr Siebeck, Tübingen. (HNT 5).

Wolter, M., 2011, 'Eschatology in Luke', in J. van der Watt (ed.), Eschatology of the New Testament and Some Related Documents, pp. 91-108, Mohr Siebeck, Tübingen. (WUNT II.315).

Zimmermann, R. (ed.), 2013, Kompendium der frühchristlichen Wundererzählungen: Band I: Die Wunder Jesu, Gütersloher Verlagshaus, Gütersloh.

Zwiep, A.W., 2004, Judas and the Choice of Matthias: A Study on Context and Concern of Acts 1:15-25, Mohr Siebeck, Tübingen. (WUNT II.187). 